\title{
Analysis of linear long-term trend of aerosol optical thickness derived from SeaWiFS using BAER over Europe and South China
}

\author{
J. Yoon, W. von Hoyningen-Huene, M. Vountas, and J. P. Burrows \\ Institute of Environmental Physics, University of Bremen, Bremen, Germany \\ Received: 17 June 2011 - Published in Atmos. Chem. Phys. Discuss.: 21 July 2011 \\ Revised: 21 November 2011 - Accepted: 22 November 2011 - Published: 7 December 2011
}

\begin{abstract}
The main purposes of the present paper are not only to investigate linear long-term trends of Aerosol Optical Thickness (AOT) at 443 and $555 \mathrm{~nm}$ over regions in Europe and South China, but also to show the uncertainty caused by cloud disturbance in the trend analysis of cloudfree aerosol. These research areas are the densely urbanised and often highly polluted regions. The study uses the Bremen AErosol Retrieval (BAER) and Sea-viewing Wide Field-ofview Sensor (SeaWiFS) data for AOT retrievals in the specified regions from October 1997 to May 2008. In order to validate the individually retrieved AOTs and the corresponding trends, AErosol RObotic NETwork (AERONET) level 2.0 data have been used. The retrieved AOTs were in good agreement with those of AERONET $(0.79 \leq R \leq 0.88$, $0.08 \leq \mathrm{RMSD} \leq 0.13)$. The contamination of the aerosol retrievals and/or AERONET observations by thin clouds can significantly degrade the AOT and lead to statistically nonrepresentative monthly-means, especially during cloudy seasons. Therefore an inter-correction method has been developed and applied. The "corrected" trends for both BAER SeaWiFS and AERONET AOT were similar and showed in average a relative difference of $\sim 25.19 \%$. In general terms, negative trends (decrease of aerosol loading) were mainly observed over European regions, with magnitudes up to -0.00453 and $-0.00484 \mathrm{yr}^{-1}$ at 443 and $555 \mathrm{~nm}$, respectively. In contrast, the trend in Pearl River Delta was positive, most likely attributed to rapid urbanization and industrialization. The magnitudes of AOT increased by +0.00761 and $+0.00625 \mathrm{yr}^{-1}$ respectively at 443 and $555 \mathrm{~nm}$.
\end{abstract}

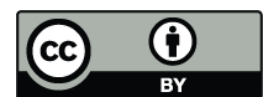

Correspondence to: J. Yoon (yoon@iup.physik.uni-bremen.de)

\section{Introduction}

The increase of anthropogenic pollutants such as urban and industrial aerosols has been identified as a serious health issue (WHO, 1987, 2000, 2005) in the past decades. These increases are attributed to substantial industrialization and change of land use. This is not only deteriorating human health in highly-populated industrial areas but also complicating the radiation balance in the atmosphere and climate systems. In order to improve the scientific understanding of aerosol changes and their impact on radiative forcing to support the evolution of environmental policy, it is necessary that the temporal changes of aerosol loading are observed globally.

The monitoring of aerosols using global retrieval techniques from satellite observations is potentially one of the most effective methods to obtain the global distribution and temporal variation of aerosol amount. Several algorithms using, for example, Advanced Very High Resolution Radiometer (AVHRR), Total Ozone Mapping Spectrometer (TOMS)/Ozone Monitoring Instrument (OMI), Along Track Scanning Radiometer (ATSR), Multi-angle Imaging SpectroRadiometer (MISR), Moderate Resolution Imaging Spectroradiometer (MODIS), and Sea-viewing Wide Field-of-view Sensor (SeaWiFS) on polar-orbiting satellites (Remer et al., 2005; Kaufman et al., 1997; Higurashi and Nakajima, 1999; Mishchenko et al., 1999; Jeong et al., 2005; Higurashi et al., 2000; Stowe et al., 1999; Heidinger et al., 2004; Torres et al., 2002; Veefkind et al., 1998; Grey et al., 2006; Thomas et al., 2009; Di Girolamo and Wilson, 2003; Martonchik et al., 2004; Diner et al., 2006; Martins et al., 2002; Robbinson et al., 2003; Wang and Shi, 2005) have been developed to retrieve the global Aerosol Optical Thickness (AOT). Up to now AVHRR, TOMS/OMI, ATSR, MISR, and MODIS have been used in the analysis of global and regional aerosol trends, because they have continuous and long-term observation histories.

Published by Copernicus Publications on behalf of the European Geosciences Union. 
Mishchenko et al. (2007) and Mishchenko and Geogdzhayev (2007) derived aerosol trends from long-term satellite records, utilizing AVHRR channels one and two over global oceans. In their publications, they provided a comprehensive data set and global/regional trends of tropospheric aerosol from August 1981 to June 2005. They concluded that the observed decrease of the global trend of tropospheric AOT may have contributed to the upward trend in surface solar fluxes. Therefore, the increase of surface sunlight more evidently proved that the climate was getting warmer during the past decade. Zhao et al. (2008) provided a more elaborate analysis for global and regional AOT trends using the AVHRR Pathfinder Atmosphere (PATMOS) climate data set. They added uncertainty tests (i.e. the effects of grid size, uncertainty in aerosol retrieval algorithm, and sensor calibration) to the AOT trend analysis and found that the difference between grid sizes when comparing monthly averaged AOT can be neglected while improper assumptions in the algorithm may produce a spurious AOT long-term trend, especially in regions dominated by industrial pollutants, biomass burning, and mineral dust. They observed negative tendencies of AOT in the regions influenced by emissions from industrialized countries or Saharan desert particles, and positive tendencies in the regions influenced by emissions from fast developing countries or smoke from biomass burning. However, although AVHRR could provide continues and long-term observations because it have been mounted on various platforms (i.e. TIROS-N, NOAA-6 19, and MetOpA), the absence of on-board calibration devices as well as the orbital drift could make a serious bias in trend analysis (Thomas et al., 2010).

Zhang and Reid (2010) explained both regional and global aerosol trends above oceans using MODIS and MISR aerosol products (2000-2009), which included both level 2 and level 3 (data assimilation) data sets. They found that both MODIS and MISR observed statistically significant increasing trends over the Indian Bay of Bengal, east coast of Asia, and Arabian Sea even though their magnitudes were slightly different. Yu et al. (2009) examined the seasonal and geographical variability of marine aerosol fine-mode fraction from MODIS collection 5 data. They found that MODIS-derived anthropogenic AOT $(550 \mathrm{~nm})$ was increasing over a 7-yr period (2001-2007) in different latitude ranges (i.e. $30^{\circ} \mathrm{N}-60^{\circ} \mathrm{N}, \mathrm{EQ}-30^{\circ} \mathrm{N}, 30^{\circ} \mathrm{S}-\mathrm{EQ}$, and $60^{\circ} \mathrm{S}-$ $60^{\circ} \mathrm{N}$ ). However, statistical analysis suggests no clear trend. They also attempted to show seasonal and geographical variations, which are consistent with the Goddard Chemistry Aerosol Radiation Transport (GOCART) and Global Modelling Initiative (GMI) model simulations. By using the 8yr MISR and MODIS-Terra data sets from March 2000 to February 2008, Kishcha et al. (2009) showed the time series of aerosol data averaged over the ocean in the latitudinal zone $\left(30^{\circ}-60^{\circ} \mathrm{N}\right)$, and found the opposite trends of AOT/FAOT (Fine Aerosol Optical Thickness) with less statistical significance (i.e. negative trend for MISR and positive for MODIS).
Thomas et al. (2010) investigated the long-term global AOT trend using ATSR-2 instrument covering time period 19952001. They derived a positive trend over the ocean rather than the negative one, consistently found with respect to the AVHRR analyses. Papadimas et al. (2008) investigated the temporal variability of AOT over the Mediterranean basin, where MODIS-Terra could monitor well aerosols due to dark surface over water. They suggested a decreasing tendency in MODIS AOT (2000-2006), which is in good agreement with corresponding AOT trends from AERONET and $\mathrm{PM}_{10}$ measurements. Up to this point, all mentioned publications focused on AOT trend derivation and analysis of the datasets, which are limited to retrievals over oceans only. In spite of relatively high accuracy of aerosol retrieval using remote sensing over ocean due to the dark and stable surface (compared to land surface), frequent cloud occurrence and disturbance for regular measurements makes it difficult to estimate the exact change in aerosol. Furthermore, the relatively short lifetime of aerosols means that these findings can not be generalized to trends of anthropogenic and natural aerosols emitted over land.

Massie et al. (2004) attempted to derive regional patterns of aerosol for global regions (land and ocean) from TOMS and their temporal trends from 1979 to 2000 . They related the trends to regional sulphur dioxide emissions and found that AOT increased clearly between 1979 and 2000 over the China coastal plain and the Ganges River basin in India. Xie and Xia (2008) examined the temporal variations of monthly AOT $(500 \mathrm{~nm})$ using TOMS from 1980 to 2001 in north China. They observed that a striking feature of AOT variation during 1997-2001 showed a clear increasing trend (especially, in spring), though a reverse tendency was revealed during 1980-1991. However, aerosol layer height and subpixel cloud contamination have a serious influence on the retrieval accuracy of aerosol using the near ultraviolet channel of TOMS (Herman, 1997; Torres et al., 1998, 2002).

Karnieli et al. (2009) provided temporal trends of anthropogenic sulphur aerosol transported from central and Eastern Europe to Israel with independent data sets such as MODISTerra, CIMEL sun/sky photometer, and $\mathrm{PM}_{10}$ Stacked Filter Unit sampler. For each research period between 1995 to 2007, MODIS-Terra (2000-2007) observed $38 \%$ reduction of fine AOT over central and Eastern Europe, a groundbased sun/sky photometer (1998-2007) showed $43 \%$ reduction in southern Israel, and the aerosol sampler (1995-2004) obtained $25 \%$ reduction of fine aerosols mass. de Meij et al. (2010) investigated the global and regional trends of AOT over land for the period of a decade (2000-2009) derived from MODIS-Terra, MISR and AERONET as well as the emission estimates from the Co-operative Programme for Monitoring and Evaluation of the Long-range Transmission of Air Pollutants (EMEP) for Europe, the Region Emission Inventory for Asia (REAS) and the Intergovernmental Panel on Climate Change (IPCC, RCP 3PD) for North America and the entire globe. They found generally negative trends over 
Europe and North America, while mostly positive ones over South and East Asia. Koukouli et al. (2010) discussed a negative trend from MODIS-Terra AOTs (2000-2006) observed over the Southern Balkan/Eastern Mediterranean. They assumed that the negative trend is going back to the decrease of local aerosol emission or the transported aerosol and the change in the wind patterns of the area in the past decade. Kaskaoutis et al. (2011) focused on analysis of aerosol load over south Asia using MODIS-Terra AOT data during the period (2000-2009), and found an increasing trend of $10.17 \%$ in AOT. Dey and Di Girolamo (2011) used ten years of MISR observations (March 2000-February 2010), and found seasonal increase in AOT in a range of 0.1-0.4 over the Indian subcontinent due to human activity. Still, it remains a challenging task to retrieve accurate AOTs over land using satellite observations (aerosol retrieval uncertainty: $\pm 0.20 \sim 0.30 \times$ AOT for TOMS (Torres et al., 2002), $\pm 0.05 \pm 0.20 \times$ AOT for MISR (Kahn et al., 2005a, 2010), and $\pm 0.05 \pm 0.15 \times$ AOT for MODIS (Remer et al., 2008; Levy et al., 2010)) because of the high spatial and temporal variability of the surface contribution, aerosol loading, and aerosol characteristics. Therefore, in order to analyze more reliable AOT trends observed from satellites, a trend comparison with ground-based observation over land has to be preceded.

Recently, there have been several analyses of aerosol trend by means of model studies. For instance, Streets et al. (2009) examined the hypothesis that AOT changes are caused by the changing patterns of anthropogenic emissions of aerosol and aerosol precursors from 1980 to 2006 using the Goddard Chemistry Aerosol Radiation and Transport (GOCART) model. They concluded that trends in man-made contributions to AOT are mainly influenced by industrial and economic activity. A step further, Leibensperger et al. (2011) simulated the aerosol direct and indirect (warm cloud) radiative forcings from US anthropogenic sources over the 19502050 period based on historical emission inventories and future projections from the IPCC A1B scenario (Nakićenović and Swart, 2000). They used the GEOS-Chem Chemical Transport Model (CTM) combined with the GISS General Circulation Model (GCM), and found that a dramatic decrease in US anthropogenic aerosol forcing has the potential to induce particularly strong warming over the US. Lei et al. (2011) derived the primary anthropogenic aerosol emission trend in China from 1990 to 2005 using model framework. They estimated the Particulate Matter $\left(\mathrm{PM}_{2.5}\right.$ and $\mathrm{PM}_{10}$ ) and Total Suspended Particulate (TSP) increased from 1990 to 1996 , and decreased until 2000, then increased again in the following years. However, in spite of the plausible conclusions, the simulations could be easily contaminated by a large error due to many assumptions in the models.

This study has two foci: firstly, The derivation of aerosol temporal trends over land and water and secondly the improvement of the trend analysis through the trend comparison with ground-based observations and investigation of cloud disturbance, thereby providing a better understanding of aerosol radiative forcing. This supports the evolution and assessment of environmental policy for air quality over Europe and South China. Previous investigations have focused on the retrieval of accurate AOT by improving sensor calibration and the AOT retrieval algorithm. Only a few have investigated AOT trends over land, where most of the anthropogenic aerosols are emitted. As mentioned before, there is a lack of investigations taking into account AOT averages contaminated by cloud within AOT trend analysis. Trend analysis based on annual, seasonal, or monthly averages could be significantly biased due to statistically non-representative averages calculated from a small number of cloud free observations.

This study analyzes the AOT trends taking this key issue into account over Europe and South China regions (BeNeLux (Belgium/Netherlands/Luxemburg), Po Valley, Eastern Europe, Eastern Mediterranean, and Pearl River Delta, shown by Fig. 1 and listed in Table 1). These centers of population have been assigned within the CityZen project (megaCITY Zoom for the Environment: EU 24 Framework Programme 7 of European Commission) as being of particular significance. Especially, most of European regions are the air pollution hotspots constituted by the densely populated cluster of large cities (Colette et al., 2011). Eastern Mediterranean has been received much interest with regard to the effects of aerosol (Gerasopoulos et al., 2011) because of the particularly high content of atmospheric aerosols in the area (Lelieveld et al., 2002). Pearl River Delta is one of the three areas in China which have experienced extremely fast economic development (Xiao et al., 2011). Rapid urbanization and industrialization over the last few decades have introduced more complexity to air pollution issues in this area (Zhang et al., 2008). CityZen aimed to determine the air pollution distribution and change in and around the selected hotspots over the last decade (http://wiki.met.no/cityzen/start).

In the following sections of this manuscript, the derivation of the linear long-term trends of AOT over selected regions using Bremen AErosol Retrieval (BAER) (von HoyningenHuene et al., 2003, 2006, 2011; Lee et al., 2004) and SeaWiFS data is explained. In order to support the AOT trend analyses over land based on space-based observations, the retrieved AOTs and trends are compared with those from ground-based AERONET level 2.0 data. In the second section BAER and data sets (SeaWiFS and AERONET data) adopted for this study will be briefly described. In the third section, we will demonstrate the retrieval accuracy of BAER by comparisons to AERONET data. In order to investigate the feasibility and uncertainty of AOT trends, we will also provide first comparisons of BAER to AERONET AOT trends by applying the inter-correction method for non-representative monthly AOTs. Additionally, uncertainties resulting from cloud disturbance are discussed in the third section. In the fourth section, seasonal and annual AOT trends derived from SeaWiFS data as well as aerosol 
Table 1. Geolocations of several regions for linear long-term trend of BAER AOT and information summary of AERONET data.

\begin{tabular}{|c|c|c|c|c|c|}
\hline $\begin{array}{c}\text { Regions for } \\
\text { BAER AOT trend }\end{array}$ & $\begin{array}{c}\text { Geolocations } \\
\text { lon. }(\min / \max ) / \operatorname{lat} .(\min / \max )\left[{ }^{\circ}\right]\end{array}$ & $\begin{array}{l}\text { AERONET stations } \\
\text { (regions) }\end{array}$ & $\begin{array}{c}\text { Geolocation } \\
\text { lon. }\left[{ }^{\circ}\right] / \text { lat. }\left[{ }^{\circ}\right] / \text { alt. }[\mathrm{m}]\end{array}$ & Purpose & Observation Period \\
\hline 1. BeNeLux & $(-1.0 / 8.0) /(48.0 / 54.0)$ & Lille (-) & $3.142 / 50.612 / 60$ & I, III & Nov $1994 \sim$ Jun 2008 \\
\hline 2. Po Valley & $(7.5 / 13.5) /(44.0 / 46.0)$ & $\begin{array}{c}\text { Ispra (-) } \\
\text { Venise (Venice) }\end{array}$ & $\begin{array}{l}8.627 / 45.803 / 235 \\
12.508 / 45.314 / 10\end{array}$ & $\begin{array}{l}\text { I, II, III } \\
\text { I, II, III }\end{array}$ & $\begin{array}{l}\text { Jun } 1997 \sim \text { Feb } 2008 \\
\text { Jun } 1999 \sim \text { Nov } 2009\end{array}$ \\
\hline 3. Eastern Europe & $(18.0 / 60.0) /(40.0 / 65.0)$ & $\begin{array}{c}\text { Toravere }(-) \\
\text { Moscow_MSU_MO } \\
\text { (Moscow) } \\
\text { Moldova (-) } \\
\text { Belsk }(-)\end{array}$ & $\begin{array}{c}26.460 / 58.255 / 70 \\
37.510 / 55.700 / 192 \\
28.816 / 47.000 / 205 \\
20.792 / 51.837 / 190\end{array}$ & $\begin{array}{l}\text { III } \\
\text { III } \\
\text { III } \\
\text { III }\end{array}$ & $\begin{array}{l}\text { Jun } 2002 \sim \text { Nov } 2008 \\
\text { Sep } 2001 \sim \text { Nov } 2008 \\
\text { Sep } 1999 \sim \text { May } 2009 \\
\text { Apr } 2002 \sim \text { Oct } 2008\end{array}$ \\
\hline 4. Eastern Mediterranean & $(22.5 / 32.5) /(30.0 / 42.0)$ & Forth_Crete (Crete) & $25.282 / 35.333 / 20$ & I, II, III & Jan $2003 \sim$ Mar 2008 \\
\hline 5. Pearl River Delta & $(112.0 / 115.5) /(22.0 / 24.0)$ & $\begin{array}{l}\text { Hong_Kong_Hok_Tsui } \\
\text { (Hong Kong) }\end{array}$ & $114.258 / 22.210 / 80$ & III & Nov 2007 Aug 2009 \\
\hline
\end{tabular}

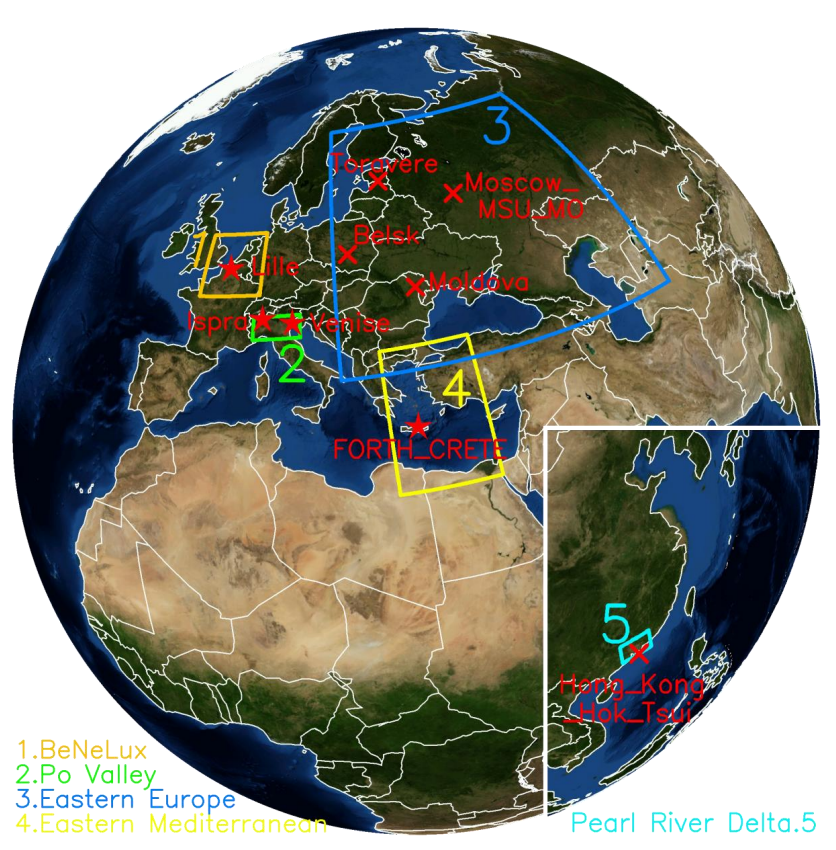

Fig. 1. Several regions (BeNeLux (Belgium/Netherlands/Luxemburg), Po Valley, Eastern Europe, Eastern Mediterranean, and Pearl River Delta in South China) for analysis of linear long-term trends of AOTs retrieved by BAER, and AERONET stations (red star or cross symbols) for three purposes described in Table 1. They are (I) validation of BAER retireved AOTs, (II) validation of BAER AOT trends, and (III) investigation of climatological aerosol characteristics. For purpose I and II, AERONET level 2.0 (pre- and post-field calibration applied, cloudscreened, and quality-assured) all-point and monthly AOTs were employed respectively. For purpose III, level 2.0 inversion all-point data (volume size distribution and Single Scattering Albedo (SSA)) were used for analysis of aerosol characteristics. Background RGB source: http://visibleearth.nasa.gov/. characteristics (volume size distribution and Single Scattering Albedo (SSA)) from AERONET inversion data will be analyzed together over specific regions shown in Fig. 1 and Table 1. Our conclusions will be summarized in the final section.

\section{Bremen AErosol Retrieval (BAER) and AERONET data sets}

The Bremen AErosol Retrieval (BAER) has been employed to retrieve AOTs over land and ocean, using various sensors (i.e. MEdium Resolution Imaging Spectrometer (MERIS), SeaWiFS, and MODIS) over specific regions. The validity of this approach has been demonstrated convincingly in previous studies (von Hoyningen-Huene et al., 2003, 2006, 2011; Lee et al., 2004). Its main features are designed using multi-spectral separation techniques to discriminate spectral surfaces and atmospheric properties. For instance, SeaWiFS data for channels 2 and 5 (443 and $555 \mathrm{~nm}$ ), both of which are less influenced by land surface are used to retrieve the AOT. On the other hand, SeaWiFS data at channels 6 and $8(670$ and $865 \mathrm{~nm})$ are utilized to estimate the surface contribution using Normalized Differential Vegetation Index (NDVI). In order to pre-calculate Look-Up-Tables (LUT) in BAER, the aerosol properties (i.e. SSA and phase function) observed during the LACE-98 (Lindenberg Aerosol Characterization Experiment; Bundke et al., 2002; Ansmann et al., 2002; von Hoyningen-Huene et al., 2003) have been used in this study. More details and further information about the uncertainties of the BAER were comprehensively discussed in von Hoyningen-Huene et al. (2011).

Before analyzing the climatological AOT change, we shall briefly discuss the aspect of radiance calibration which is a well-known major source of uncertainty in AOT retrievals (Higurashi and Nakajima, 1999; Ignatov and Stowe, 
2002). Several calibration methods, e.g. pre- or post-launch calibrations using deep convective clouds, vicarious calibration, inter-satellite calibration, lunar calibration, and comparison with in situ data, have been applied and discussed thoroughly by Li et al. (2009). Recently, calibration accuracies have been improved remarkably, but differ between modern (MISR; 3\% accuracy (Kahn et al., 2005b; Bruegge et al., 2007), MODIS; 2\% accuracy ( $\mathrm{Li}$ et al., 2009)) and "transitional" sensors (AVHRR-GACP; 5\% accuracy (Rossow and Sciffer, 1999), AVHRR-PATMOS; 3-5\% accuracy (Heidinger et al., 2002), TOMS; $\sim 2 \%$ accuracy (Li et al., 2009)). From the perspective of on-board, lunar (Barnes et al., 2001), and vicarious calibrations (Gordon, 1998; Eplee et al., 2001), SeaWiFS is one of the most accurate and stable sensors (0.5\% accuracy and $0.3 \%$ stability (Li et al., 2009), $5 \%$ absolute and $1 \%$ relative radiometric accuracies (Eplee et al., 2007; Franz et al., 2007)). Especially, because the calibration errors of any sensor are usually amplified by the atmospheric correction, the $1 \%$ relative accuracy of SeaWIFS converted into a $0.1 \%$ long-term radiometric stability for TOA radiances (Eplee et al., 2011). Therefore, we could assume that the sensor degradation of SeaWiFS might be a negligible effect in this study. An example of SeaWiFS normalized radiances by applying the lunar calibration in the fifth reprocessing for channels $2,5,6$, and $8(443,555,670$, and $865 \mathrm{~nm}$, respectively) is depicted in Fig. 2. In BAER, the band 2 and 5 (443 and $555 \mathrm{~nm}$ ), which have weaker effect from land surface, were used to retrieve AOT. On the other hand, band 6 and 8 (670 and $865 \mathrm{~nm})$ were utilized to estimate the surface contribution using Normalized Differential Vegetation Index (NDVI). The degradation in band 8 might induce an error to account for the surface contribution in the AOT retrieval. Uncertainties for aerosol retrieval by BAER were discussed comprehensively in von Hoyningen-Huene et al. (2010).

SeaWiFS has provided almost continuous and wellcalibrated radiances since its launch in August 1997. However, there is a lot of missing observations from 2008 to 2010 (Patt, 2010). In addition, it has a shift in the measurement time (caused by orbital drift), which started in around 2002 (Eplee et al., 2011). These could induce significant uncertainties in the trend analysis because AOT over the regions close to local aerosol sources (e.g. urban regions, dry deserts, and slash-and-burn agricultural regions) have clear and strong diurnal variability (Smirnov et al., 2002). Therefore, this study employed SeaWiFS level 1 (L1B) data from October 1997 to May 2008 in order to minimize such biases caused by the time shift (which is within around one hour till May 2008) and the missing observations. More detailed information on the major instrument parameters and characteristics of SeaWiFS were presented in Hooker et al. (1992) and Cracknell et al. (2001).

In order to validate the results retrieved using BAER, level 2.0 (pre- and post-field calibration applied, cloudscreened, and quality-assured) AERONET data were used

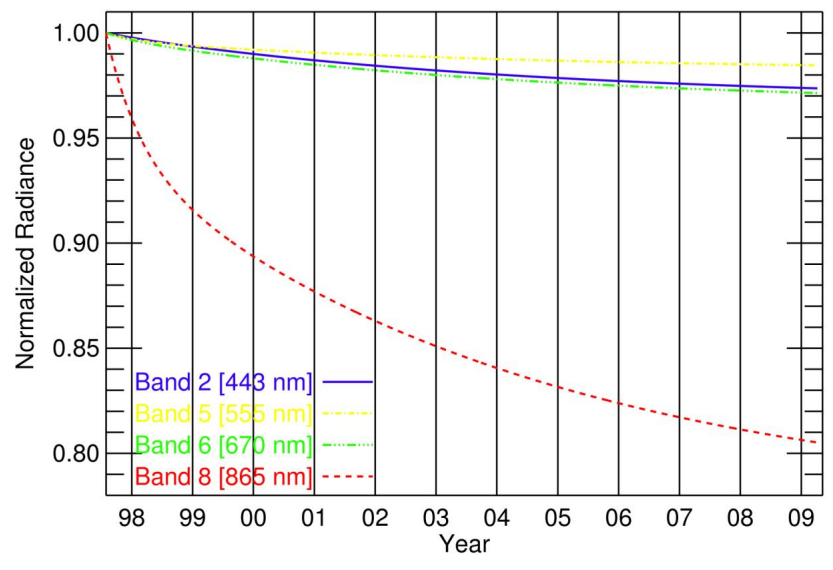

Fig. 2. SeaWiFS normalized radiances by lunar calibration in the fifth reprocessing at bands $2,5,6$, and $8(443,555,670$, and $865 \mathrm{~nm}$, respectively) after launched.

(Holben et al., 1998, 2001; Eck et al., 1999; Smirnov et al., 2000). This network of ground-based observations does not only provide accurate AOTs (accuracy; \pm 0.01 (Holben et al., 1998)), but also various aerosol characteristics (volume size distribution, complex index of refraction, phase functions, SSA, and more). The AERONET inversion process and research activities were described by Dubovik and King (2000), Dubovik et al. (2000, 2001, 2002, 2006), and Sinyuk et al. (2007). In this study, the volume size distribution and SSA were selected to understand seasonal and annual aerosol characteristics at all available AERONET stations within the selected regions (Table 1). Even though there are a lot of AERONET stations within the regions, not all stations are suitable for the validations of AOTs and AOT trends because they do not distribute sufficiently long-term and continuous records of AOT (Yoon et al., 2011). Furthermore, BAER has still limitations to retrieve AOT using SeaWiFS data (only in visible wavelength range) over some regions, which are easily affected by frequent cloud disturbance or/and high surface reflectance. Especially, at some AERONET stations in Pearl River Delta (Hong Kong) and at higher latitude in Eastern Mediterranean it is difficult to compare BAER with AERONET AOTs. Therefore, the only few AERONET stations, which have been chosen in the paper, could be used for validations. Table 1 shows the AERONET stations chosen for three purposes: (I) validation of BAER retrieved AOTs, (II) validation of BAER AOT trends, and (III) investigation of climatological aerosol characteristics.

\section{Validation of BAER retrieved AOTs and their trends}

For obvious reasons, the validation process of the AOT retrievals based on satellite observations is an important part in this study. Therefore, an analysis of the reliability and accuracy of BAER retrieved AOTs at 443 and $555 \mathrm{~nm}$ is 
required and achieved by comparison to independent data. In this study, AERONET level 2.0 AOTs at selected stations (locations labelled with red stars in Fig. 1) having a long observation history (more than five years) were used for the validation. As mentioned in Sect. 2, only four AERONET stations could be used in this validation section due to the limitation of aerosol retrieval using BAER and SeaWiFS. The AERONET AOT at $555 \mathrm{~nm}$ was derived using AERONET Ångström Exponent (computed by two AOTs at 440 and $675 \mathrm{~nm}$ ) and AOT at $675 \mathrm{~nm}$. Prior to the validation process, an essential step is to identify and remove cloudcontaminated scenes from the satellite retrievals. Cloud pixels were screened out by (1) a reflectance threshold for the minimum cloud reflectance (Kokhanovsky, 2001), (2) checking for decreased spectral Top Of Atmosphere (TOA) reflectance in the blue bands, (3) checking for increased heterogeneity within $5 \times 5$ pixels, and (4) adjacency effects around clouds (von Hoyningen-Huene et al., 2011). Despite these rigorous cloud-masking schemes, clouds could still remain one of the most serious factors in the uncertainty of aerosol retrieval. In order to reduce the remaining impact due to cloud contamination, we have applied an additional cloud filtering method for cases where the averaged AOT exhibits high standard deviation.

\subsection{Validation of BAER AOTs}

In Fig. 3a-d, AOTs retrieved using BAER were validated with AERONET AOTs at 443 (diamond symbol) and $555 \mathrm{~nm}$ (square symbol) over stations in Lille, Ispra, Venice, and Crete for the observation period available, as shown in Table 1 . In order to make a comparison between AERONET and BAER data, we used the temporal averages of AERONET AOTs within \pm 30 min compared with the SeaWiFS over-passing time and the spatial averages of $0.12^{\circ} \times 0.12^{\circ}$ pixels of BAER AOTs compared with the location of AERONET station. The correlation coefficient $(R)$, Relative RootMean-Square Difference (RMSD), and linear correlation equation $(y=A x+B)$ between them generally revealed good agreement $(0.79 \leq R \leq 0.88, \quad 0.08 \leq \mathrm{RMSD} \leq 0.13$, $0.762 \leq A \leq 0.988$, and $-0.031 \leq B \leq 0.067$ ) at all stations. In general, the retrieval accuracy is following the guide dotlines in Fig. 3, which present the error range or uncertainty of BAER AOT retrieval: $\pm 0.05 \pm 0.25 \times$ AOT (von Hoyningen-Huene et al., 2011). Slope (A) closer to 1 means the appropriateness of aerosol properties, which are used in the pre-calculation of LUT. Intercept $(B)$ closer to 0 shows how accurate surface contribution is considered in aerosol retrieval. Furthermore, a large error bar on the points could present the possibility of cloud contamination. Clearly, there still were some discrepancies, caused by three main factors: (1) unscreened clouds, (2) incorrect surface reflectance, and (3) inadequate aerosol optical properties assumed in BAER. The BAER's retrieval accuracy over other regions, USA, Eu- rope, and East Asia, was shown and discussed in Lee et al. (2004) and von Hoyningen-Huene et al. (2011) in detail.

\subsection{Validation of BAER AOT trends}

Even though previous validations indicated that BAER and AERONET AOTs are in good agreement, it remains important to ensure that AOT trends retrieved using satellite observations are highly reliable. This is achieved by undertaking an additional validation of BAER and AERONET AOT trends. First, a simple linear model, which is used to minimize chi-square error statistics, was adopted for the estimation of both trends. In order to analyze accurate trends, the simple model needs to be analyzed with respect to AOT variability, which is usually autocorrelated (Zhao et al., 2008). Even though this linear model may not be the real, it allows a simple approximation of direction and magnitude of the changes in the data for many practical purposes (Weatherhead et al., 1998). Many previous studies also have adopted the simple model for AOT trend analysis (Mishchenko et al., 2007; Mishchenko and Geogdzhayev, 2007; Zhao et al., 2008; Papadimas et al., 2008; Yu et al., 2009; Xie and Xia, 2008; Kishcha et al., 2009; Karnieli et al., 2009; de Meij et al., 2010; Kaskaoutis et al., 2011). This study used the simple linear model for AOT trend comparisons. However, obviously it is not ideal to handle a whole-year of data including a clear seasonal variation of the AOT. Therefore, we considered the seasonality in the comparison by working with seasonal trends.

Let $Y_{\mathrm{t}}$ be the monthly AOT values, which are calculated with daily AOTs in a month. The linear trend model is given by Eq. (1), where $\mu$ is a constant term and $\omega$ is the magnitude of the trend per year $\left(X_{t}=t / 12\right)$.

$Y_{t}=\mu+\omega X_{t}+N_{t}, \quad t=1, \cdots, T$.

To investigate the effects of the magnitude and autocorrelation of noise on the estimated trend, the noise $N_{\mathrm{t}}$ is assumed to be autoregressive of first order like in Eq. (2), where $\varepsilon_{t}$ is an independent random variable and $\phi$ is autocorrelation coefficient with $-1<\phi<1$ (Weatherhead et al., 1998):

$N_{t}=\phi N_{t-1}+\varepsilon_{t}$.

The estimated trend $(\hat{\omega})$ is determined by minimizing the chisquare error statistics, the variance $\left(\sigma_{N}^{2}\right)$ of the noise $\left(N_{t}\right)$ is obtained, and also related to the variance $\left(\sigma_{\varepsilon}^{2}\right)$ of the white noise $\left(\varepsilon_{t}\right)$ by the following equation:

$\sigma_{N}^{2}=\operatorname{Var}\left(N_{t}\right)=\frac{\sigma_{\varepsilon}^{2}}{\left(1-\phi^{2}\right)}$.

Finally, the precision or uncertainty of the trend is given by the following equation:

$\sigma_{\hat{\omega}} \approx \frac{\sigma_{\varepsilon}}{(1-\phi)} \frac{1}{n^{3 / 2}}=\frac{\sigma_{N}}{n^{3 / 2}} \sqrt{\frac{1+\phi}{1-\phi}}$, 

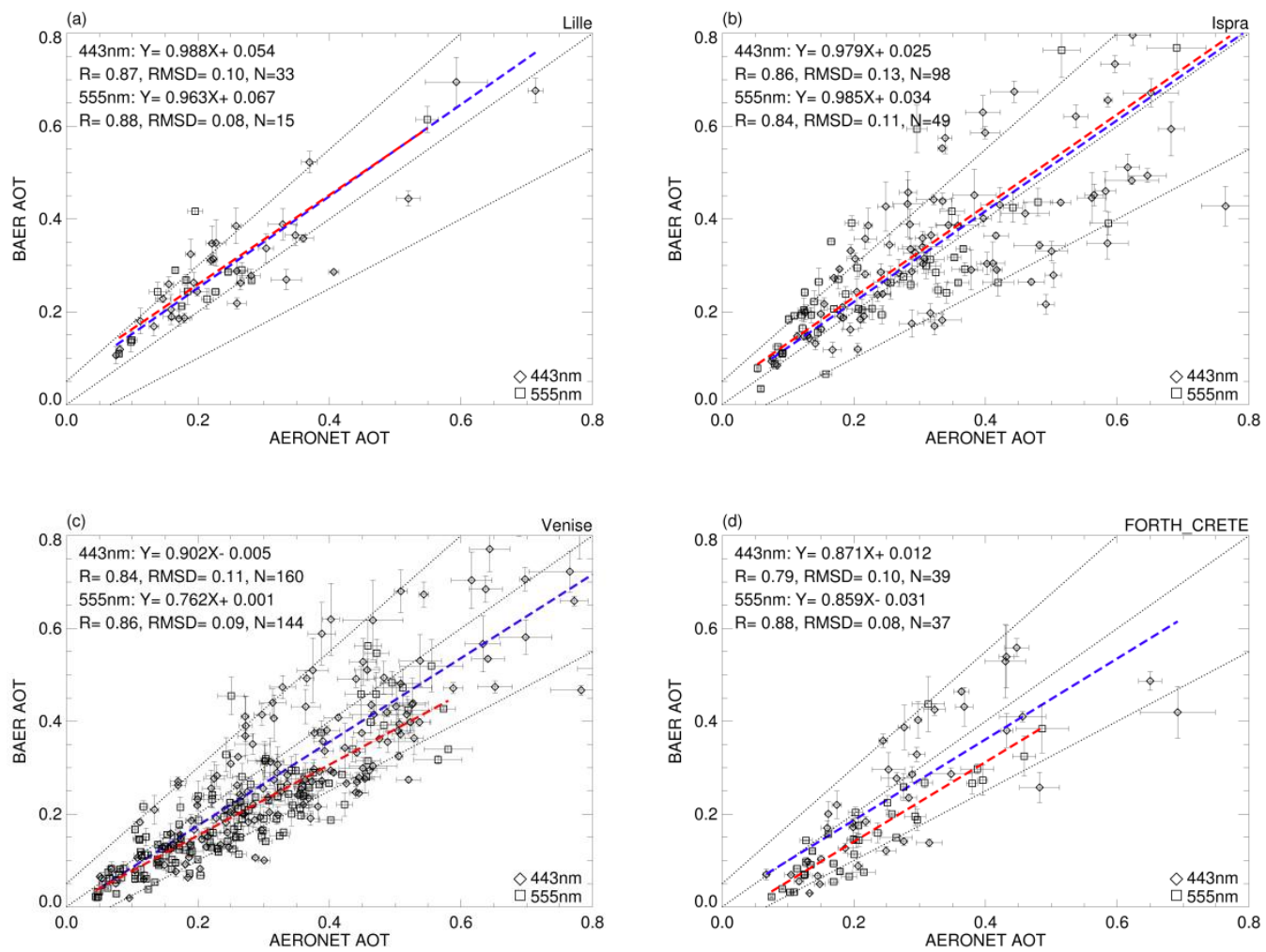

Fig. 3. Validation between BAER and AERONET AOTs (443 and $555 \mathrm{~nm}$ ) at (a) Lille, (b) Ispra, (c) Venice (Venise), and (d) Crete (Forth_Crete). Linear correlation equations between them are shown as correlation blue/red lines at 443 and $555 \mathrm{~nm}$. The guide dot-lines shows the error range of BAER AOT retrieval: $\pm 0.05 \pm 0.25 \times$ AOT (von Hoyningen-Huene et al., 2011).

where $n=T / 12$ denotes the number of years. Additionally, we have adopted a common decision rule that the trend is supposed to be real when the significance $\left(\left|\hat{\omega} / \sigma_{\hat{\omega}}\right|\right)$ of the trend is larger than two at a $5 \%$ significance or $95 \%$ confidence level (Tiao et al., 1990).

Figures 4 and 5 depict the linear trends of BAER and AERONET monthly AOTs at 443 and $555 \mathrm{~nm}$. Generally, negative trends are similar for both data sets, but their magnitudes are quite different. Especially, the significance values of BAER trends are poor $\left(\left|\hat{\omega} / \sigma_{\hat{\omega}}\right| \ll 2\right)$, except for the values from Venice $\left(\left|\hat{\omega} / \sigma_{\hat{\omega}}\right|=1.58\right.$ and 1.72 at 443 and $\left.555 \mathrm{~nm}\right)$.

In order to have statistical significant, sufficient observations are required, and the cloud disturbance leads to reduced the observation numbers in aerosol retrieval. The presence of clouds influences AOT retrievals in three ways (Husar et al., 1997; Haywood et al., 2001; Jeong and Li, 2005; Jeong et al., 2005): by (1) contamination of thin cloud as aerosol loading, (2) misclassification of strong aerosol loading as clouds, and (3) biasing aerosol sampling due to a lack of retrievals in presence of clouds.

Thin cloud contamination causes the retrieved AOT to be overestimated. Therefore, to distinguish thin cloud pixels, many algorithms have adopted very rigid filtering methods. However, this strategy causes another side effect linked to the lack of possible retrievals. The second effect leads (on average) to an underestimated AOT due to the removal of pixels dominated by heavy aerosol loading. This underestimation could not easily be quantified in previous validations (Fig. 3) as misclassified aerosols were already removed by cloud masking. In particular, the second effect can induce more serious errors to calculate climatological data (e.g. monthly, seasonal, annual average of global and regional AOTs) and their trends. The third effect generates a random-like error. The uncertainty from the third effect leads to over- or underestimation of the AOT because cloudy days are underrepresented in the database (Remer et al., 1997; Dubovik et al., 2001). Overall, the three superimposed cloud effects can have a complicated influence on the quality of AOT retrievals, as seen in the difference between AERONET and BAER AOT trends (Figs. 4 and 5). For the consideration of the first and second cloud effects, we have introduced a histogram analysis (right axis in Figs. 4 and 5). Based on statistical and visual analysis we defined nonrepresentative monthly AOTs (shown as red triangle symbols in Figs. 4 and 5) when less than five daily AOTs for BAER retrievals and ten for AERONET. According to these criteria, the AERONET station of Lille has been excluded from this study because most of the BAER AOT retrievals were non-representative. 

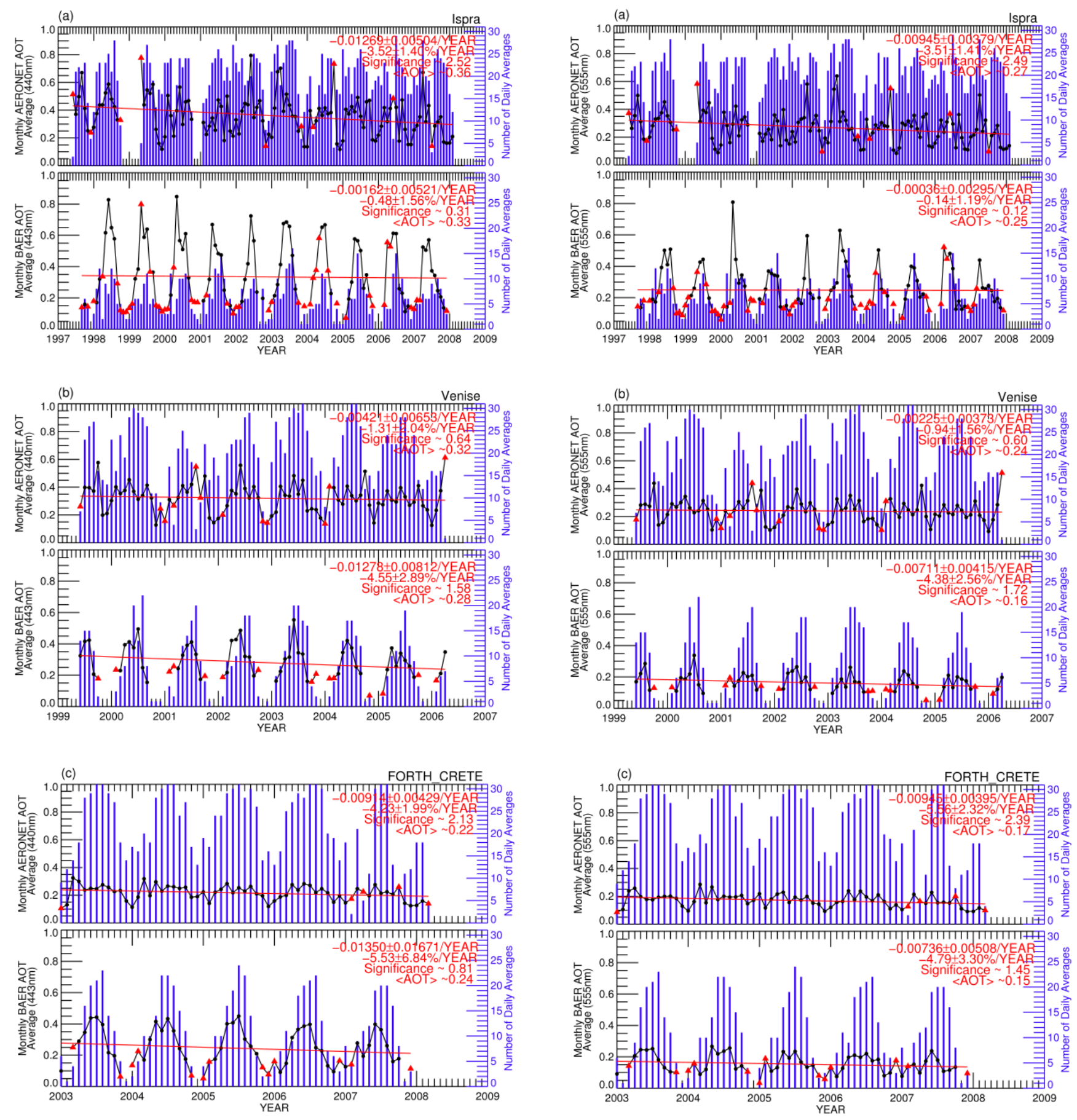

Fig. 4. Total AOT averages $(<\mathrm{AOT}>$ ) and statistical parameters for linear long-term trends of AERONET and BAER AOTs (443 nm, black circle and red triangle symbols) at (a) Ispra, (b) Venice (Venise), and (c) Crete (Forth_Crete). Non-representative monthly AOTs (red triangle symbol) were defined as the average of less than five daily AOTs from BAER and ten from AERONET. Blue histograms show daily observation number per each month (right axis).

Fig. 5. As in Fig. 4, but for $555 \mathrm{~nm}$. 
For a direct comparison between the trends of AERONET and BAER under the same conditions, non-representative monthly AOTs have been inter-corrected from the opposite dataset (representative values) using the linear correlation equations (blue and red correlation lines shown in Fig. 3). Through this approach, we received a better agreement between BAER and AERONET AOT trends. Figures 6 and 7 show both trends based on inter-corrected (blue diamond symbol) and representative monthly AOT (black circle symbol) at 443 and $555 \mathrm{~nm}$ including their statistical significance. Negative trends prevailed for all AERONET stations considered. Magnitudes of both trends now agree much better and their statistical significance improved. Most of the intercorrections were done for data measured in winter time.

Figure 8 shows linear long-term AOT trends before (red) and after (blue) applying the inter-correction method described above. Clearly, the trends of the BAER AOT and those of AERONET agree within error (average of relative difference $\sim 25.19 \%$ ) after application of this method. However, as mentioned, the linear model is not appropriate to handle whole-year data due to the clear seasonal variation of AOT. Therefore, the validation in Fig. 8 could be not enough to show the improvement of the trend analysis by applying inter-correction method. In addition, Fig. 9 shows the trend comparison of seasonal AOTs as in Fig. 8. The validation of the AOT trends including poorly representative values (red) shows an anti-correlation, whereas other does not (blue). Through these validations (Figs. 8 and 9), we conclude that one of the most serious factors leading to the difference of trend magnitudes is cloud disturbance, which leads to reduced observation numbers in the statistics.

\section{Linear long-term AOT trends and aerosol characteristics over Europe and South China}

Aerosol characteristics are variable in time and region because of its different aerosol sources (e.g. aerosol types and emission intensity) and different atmospheric conditions (e.g. relative humidity and boundary layer height). The regions defined in this paper are affected by huge human activity. Figure 10 shows the seasonal distributions of BAER AOTs $(443 \mathrm{~nm})$, which are good at examining the seasonal variation of AOT in the regions. Over European regions (BeNeLux, Po Valley, Eastern Europe, and Eastern Mediterranean), aerosols have a strong seasonal variation because industrial pollution composed of sulphur is enhanced during summer, when the solar radiation at the surface maximizes (Marmer et al., 2007; Karnieli et al., 2009). Furthermore, forest fires in Southern Europe, occurring mostly in summer, may well contribute to seasonal variation (Pace et al., 2006; Tafuro et al., 2008) and significant dust loads coming from northern African deserts are frequently observed over Mediterranean in spring and summer (Hatzianastassiou et al., 2009). Additionally, the absence of removal processes (e.g. rain and monsoon) as
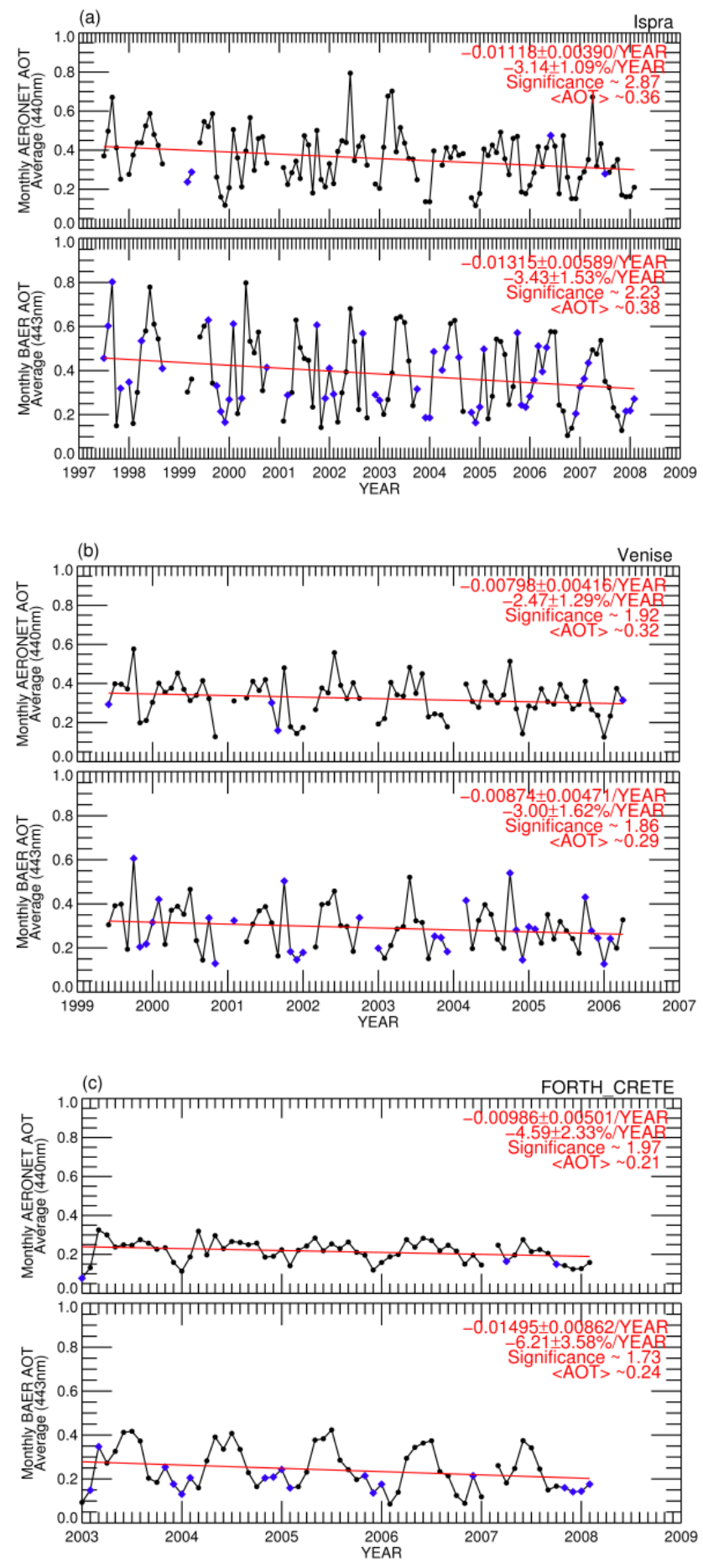

Fig. 6. Total AOT averages $(<\mathrm{AOT}>)$ and statistical parameters for linear long-term trends of representative and inter-corrected AOTs (443 nm, black circle and blue diamond symbols) from AERONET and BAER at (a) Ispra, (b) Venice (Venise), and (c) Crete (Forth_Crete). The non-representative monthly AOTs (red triangle symbols in Fig. 4) are inter-corrected using the linear correlation equations in Fig. 3. 

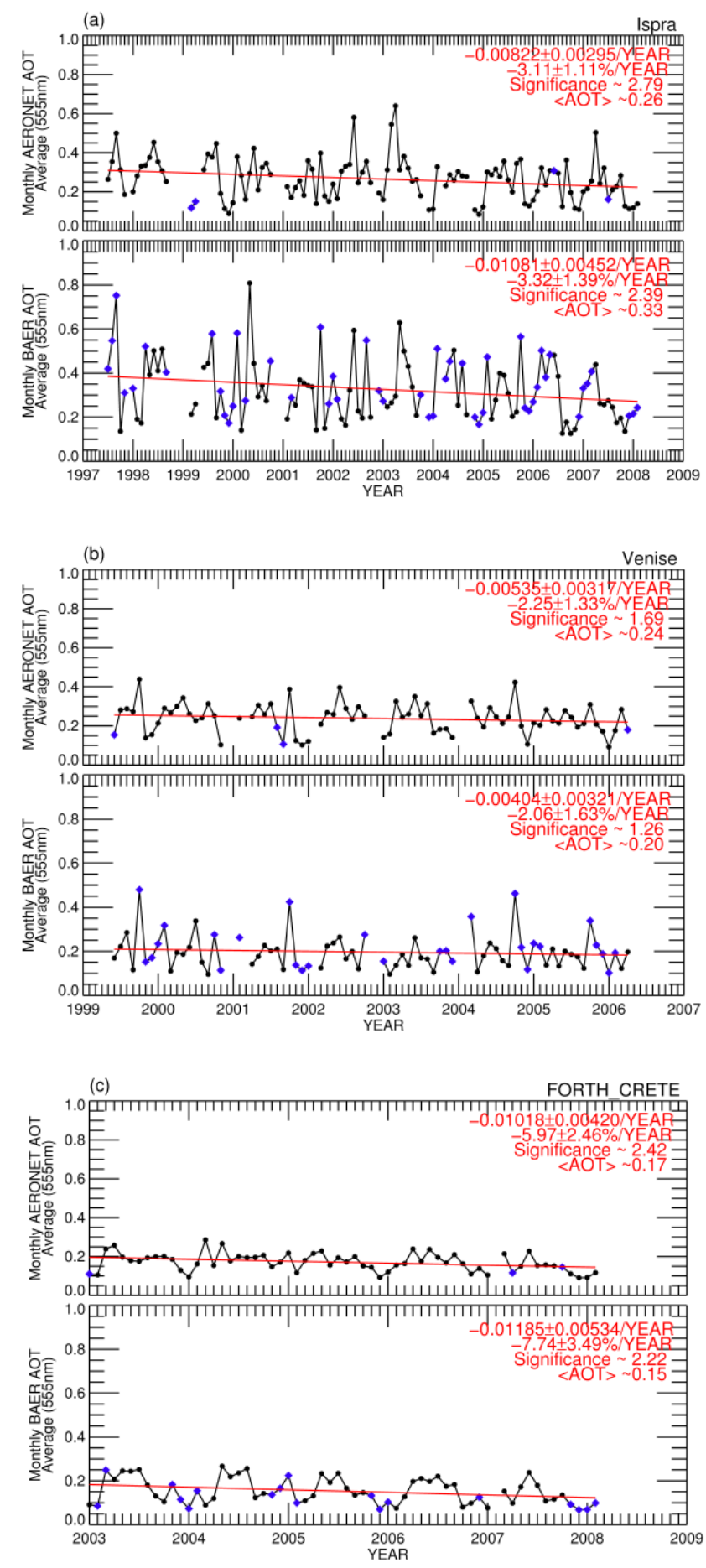

Fig. 7. As in Fig. 6, but for $555 \mathrm{~nm}$. The non-representative monthly AOTs (red triangle symbols in Fig. 5) are inter-corrected using the linear correlation equations in Fig. 3.

well as a high boundary layer height causes higher AOTs in summer over Europe (Hatzianastassiou et al., 2009; Gerasopoulos et al., 2003; Bergamo et al., 2008; Venzac et al., 2009). Over the Pearl River Delta in South China, seasonal

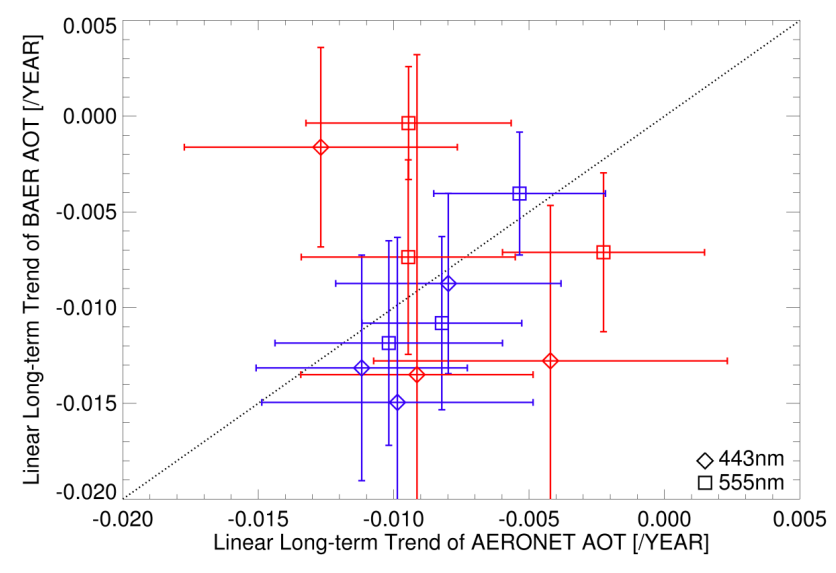

Fig. 8. The trend validation of AERONET and BAER AOTs (443 and $555 \mathrm{~nm}$ ) based on comparison between before (red) and after applying the inter-correction method (blue) at Ispra, Venice (Venise), and Crete (Forth_Crete).

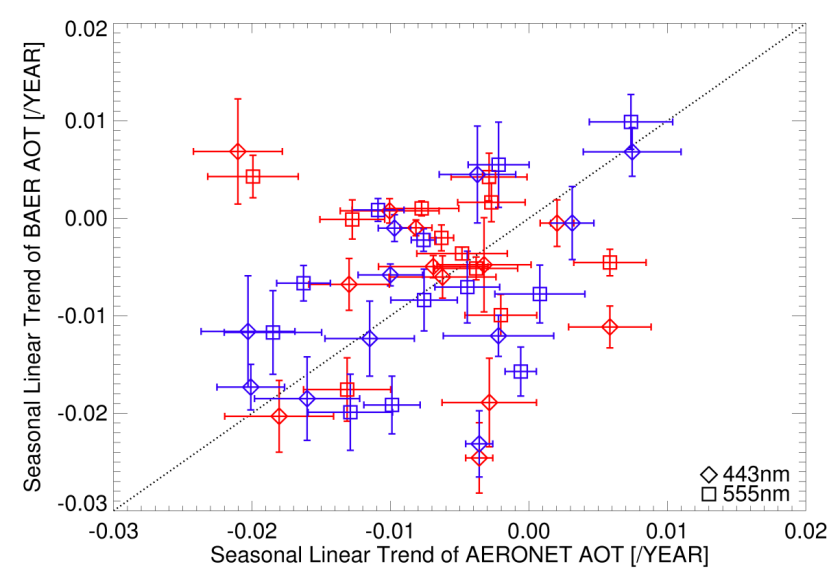

Fig. 9. As in Fig. 8, but on a seasonal basis.

aerosol variations are mainly influenced by typical anthropogenic aerosols, caused by urbanization and industrialization as well as a hygroscopic growth with stagnant synoptic meteorological patterns in summer (Xiao et al., 2011; Zhang et al., 2008).

Figure 11 shows the linear long-term trends of BAER retrieved AOTs over the several regions (BeNeLux: -0.00453 and -0.00484 , Po Valley: -0.00386 and -0.00440 , Eastern Europe: -0.00055 and -0.00019 , Eastern Mediterranean: -0.00079 and -0.00054 , and Pearl River Delta: +0.00761 and $+0.00625 \mathrm{yr}^{-1}$ at 443 and $555 \mathrm{~nm}$, respectively). Except for the case of Pearl River Delta in South China, negative trends were observed in all analyzed regions. These are comparable to Zhang and Reid (2010), which estimated the negative trends of MODIS-Terra and MISR AOTs $(-0.009 \sim-0.022 /$ decade $)$ over Mediterranean Sea and positive $(+0.002 \sim+0.014 /$ decade $)$ ones over Southeast Asia from March 2000 to December 2009. 

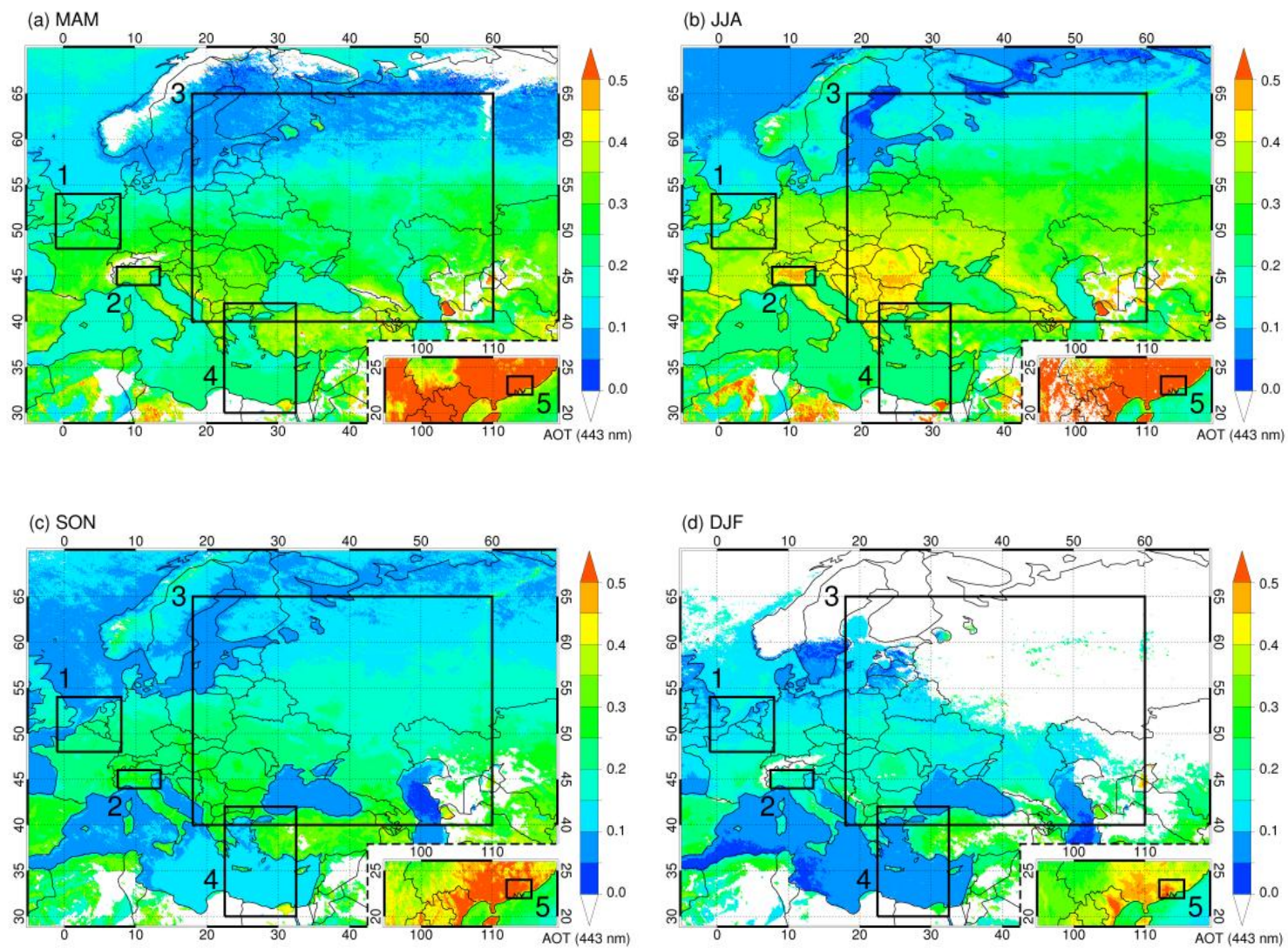

Fig. 10. Seasonal distribution of BAER AOT $(443 \mathrm{~nm})$ over the specific regions. The BAER AOTs over bright surface (e.g. Northern African deserts and the Anatolian plateau) or under frequent cloud disturbance are underestimated.

de Meij et al. (2009) also found that AOT is decreasing $\left(-0.00042 \sim-0.00011 \mathrm{yr}^{-1}\right)$ over Europe and increasing $\left(+0.00063 \sim+0.00189 \mathrm{yr}^{-1}\right)$ over Asia observed from AERONET, MODIS-Terra, and MISR during $10 \mathrm{yr}(2000$ 2009). Specifically for Mediterranean basin, Papadimas et al. (2008) reported a negative MODIS-Terra AOT trend $\left(-0.00002 \mathrm{yr}^{-1}\right)$ from 2000 to 2005 . Koukouli et al. (2010) estimated the downward trends (2000-2006) of MODISTerra AOTs: $-1.85 \%,-3.50 \%,-4.18 \%$, and $-4.20 \%$ per annum at Aegean Sea, Heraklion, Mount Athos, and Thessaloniki over Southern Balkan/Eastern Mediterranean. Additionally, using TOMS data (1980-2001), Hatzianastassiou et al. (2009) found a significant decrease of AOT $(-3.8 \% \sim-20.9 \%)$ in eastern Mediterranean basin. Definitely, the AOT trends from the many different studies are difficult to be compared each other directly because of different research periods, sampling times, sensor calibrations, aerosol retrieval accuracies, and so on. However, they could be relatively close in same regions. In general, these findings of the previous studies are consistent with the BAER AOT trends in the present paper.
As explained earlier, practically all AOT trends based on satellite observations having the influence of cloud disturbance need to be corrected due to cloud uncertainties. However, the inter-correction as applied ignores the difference in spatial resolution of the two data sets. Therefore, we have tried to roughly estimate the cloud uncertainties by a separate analysis of trends for each season (as shown in Fig. 12 and Table 2). Additionally, through dealing seasonal trends with the linear model, uncertainty from the AOT seasonality in trend analysis could be reduced.

Strong downward trends of BAER AOTs in the spring and summer appear over most of European regions. They are similar with Zhao et al. (2008), which discussed the negative trend of AVHRR AOTs during $25 \mathrm{yr}$ (1981-2004) over oceans near the regions in spring and summer, and magnitude was up to -0.1 per decade. Karnieli et al. (2009) also found practically same results, decreasing trends of MODISTerra AOTs $\left(-0.01 \mathrm{yr}^{-1}\right)$ and fine AOTs $\left(-0.009 \mathrm{yr}^{-1}\right)$ for July and August over central and Eastern Europe. The strong decreases of AOT over the BeNeLux and Po Valley regions are attributed to the strict environmental regulations for mitigating climate change and improving air quality (Smith et al., 2001; Streets et al., 2006; Zhao et al., 2008). Especially, for the broader Mediterranean basin, Papadimas et 

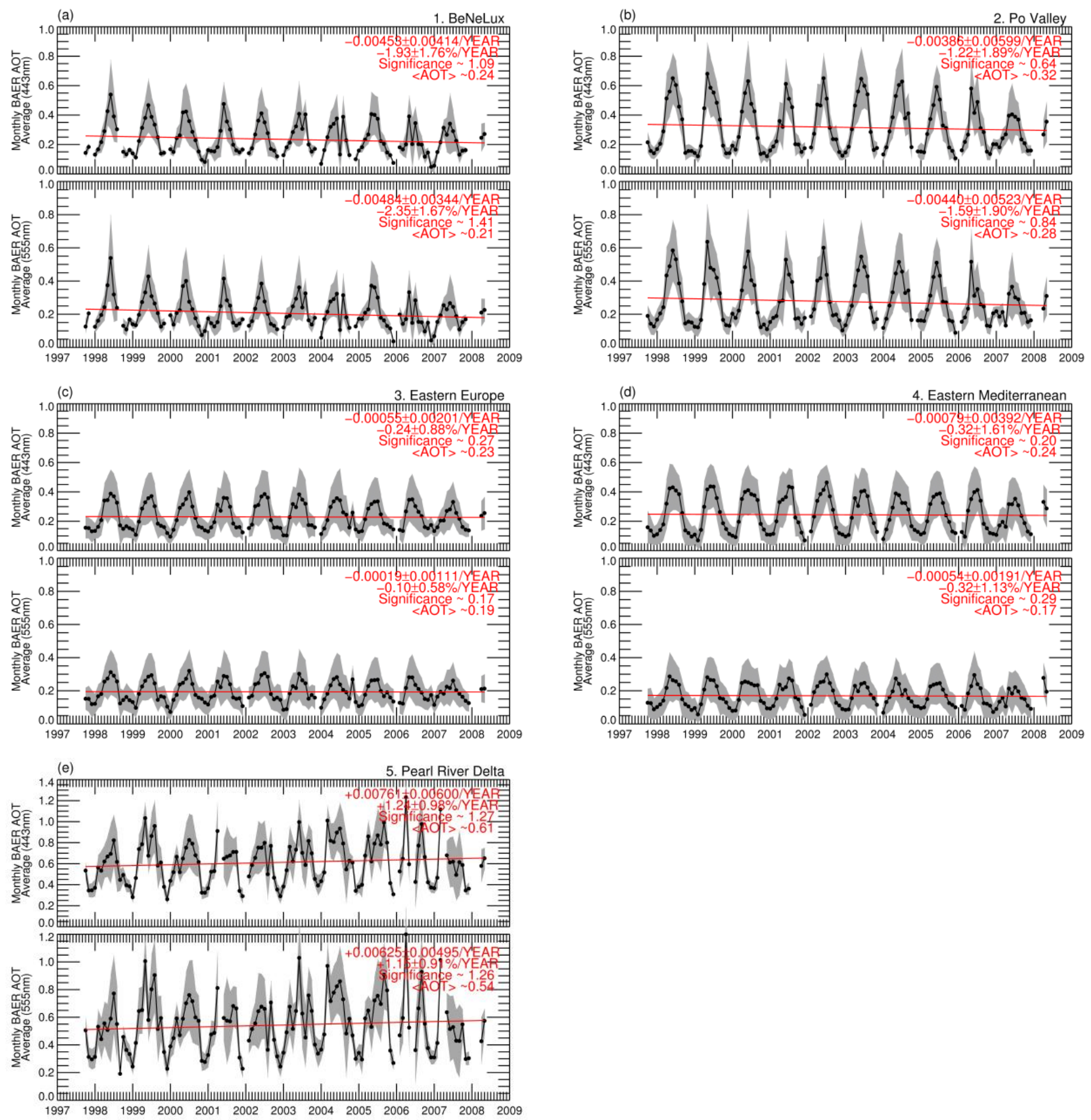

Fig. 11. Total averages $(<\mathrm{AOT}>$ ) and linear long-term trend of BAER monthly AOTs (black circle symbol) including monthly standard deviation (shaded area) over (a) BeNeLux, (b) Po Valley, (c) Eastern Europe, (d) Eastern Mediterranean in Europe, and (e) Pearl River Delta in South China shown in Fig. 1. The bottom figures for each region correspond to $555 \mathrm{~nm}$ whereas the top figures to $443 \mathrm{~nm}$. 


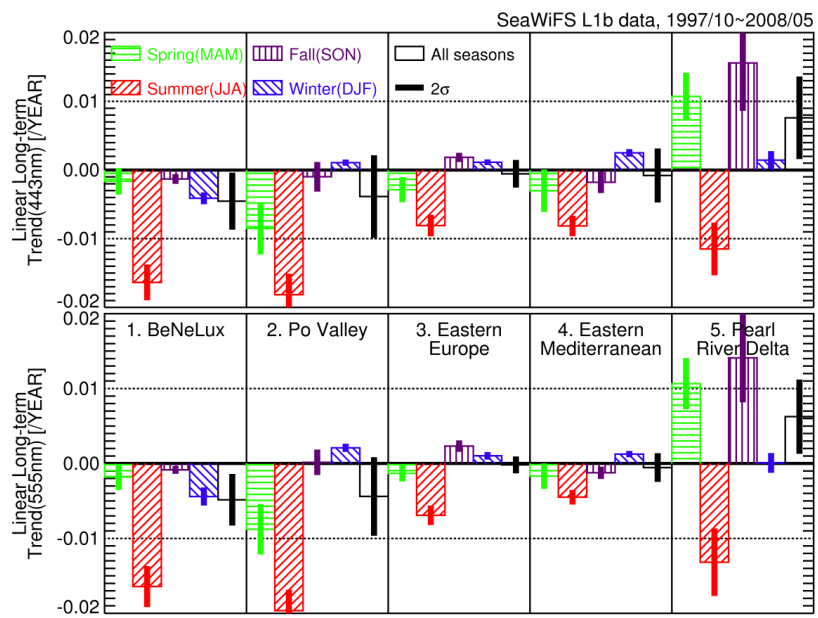

Fig. 12. Annual and seasonal trends $(\hat{\omega})$ of BAER monthly AOTs (443 and $555 \mathrm{~nm}$ ) including their standard deviation $\left(\sigma_{\hat{\omega}}\right)$ for the several regions.

al. (2008) found that MODIS-Terra AOTs from 2000 to 2006 were decreased $\left(-0.0014 \mathrm{yr}^{-1}\right)$ in summer and increased $\left(+0.0012 \mathrm{yr}^{-1}\right)$ in winter, which could be confirmed again in the present paper. These could be explained with the seasonal trends of precipitation, which are correlated inversely with them. However, in comparison with the BeNeLux and Po Valley regions, no significant trends could be found over Eastern Mediterranean and Eastern Europe regions because these regions are affected by various kinds of aerosols (e.g. sea salt, dust, industrial, and biomass burning) and change of meteorological patterns.

Over the Pearl River Delta region, almost in all seasons (except summer), the seasonal trends of BAER AOT are positive, which are caused by the rapid urbanization and industrialization in the last two decades (Streets et al., 2006; Smith et al., 2001). Zhao et al. (2008) have produced similar results that positive seasonal trends of AVHRR AOTs from 1981 to 2004 prevails in all seasons except summer, and maximal magnitude is +0.04 per decade (while it is very close to zero for summer) due to a fast development in the economy and associated enhancement of industrial emissions of the surrounding countries. The similar positive trends also have been reported in Massie et al. (2004) using TOMS AOTs from 1979 to 2000 in Asia.

Generally speaking, a lot of clouds are observed in winter over Europe and summer over South China. As shown in Sect. 3, in order to get more reliable trend of cloud-free aerosol, cloud disturbance should be considered. The trends in summer over most of the European regions (BeNeLux, Po Valley, Eastern Mediterranean, and Eastern Europe) were strongly negative with high significance, while some positive trends in cloudy seasons were also observed. This positive trend in winter could be explained with the removal processes of aerosol (i.e. negative trend of precipitation) and
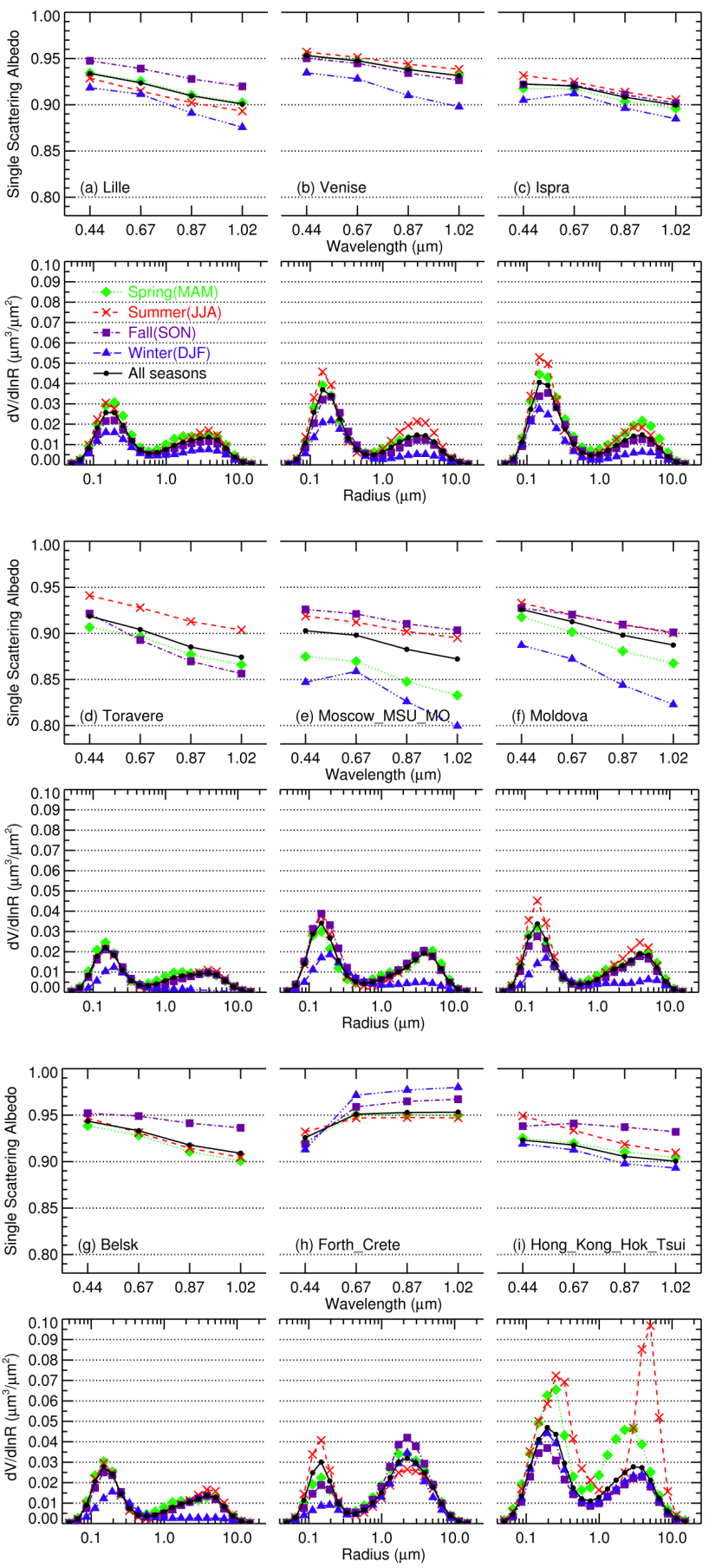

Fig. 13. Annual and seasonal aerosol characteristics (volume size distribution and Single Scattering Albedo (SSA)) from AERONET level 2.0 inversion data at (a) Lille, (b) Venice (Venise), (c) Ispra, (d) Toravere, (e) Moscow (Moscow_MSU_MO), (f) Moldova, (g) Belsk, (h) Crete (Forth_Crete), and (i) Hong Kong (Hong_Kong_Hok_Tsui) within the specific regions. 
Table 2. Statistical parameters for linear long-term trends of AOTs (443 and $555 \mathrm{~nm}$ ) retrieved by BAER over several regions.

\begin{tabular}{|c|c|c|c|c|c|c|c|}
\hline \multirow{2}{*}{ Regions } & \multirow{2}{*}{ Seasons* } & \multirow{2}{*}{$\begin{array}{c}\left\langle\tau_{\lambda}\right\rangle^{\mathrm{a}}(443 / 555 \mathrm{~nm}) \\
{[\text { dimensionless] }}\end{array}$} & \multicolumn{2}{|c|}{$\hat{\omega}_{\lambda}^{\mathrm{b}}(443 / 555 \mathrm{~nm})$} & \multicolumn{2}{|c|}{$\sigma_{\hat{\omega}_{\lambda}}^{\mathrm{c}}(443 / 555 \mathrm{~nm})$} & \multirow{2}{*}{$\begin{array}{c}\text { Sig. }^{\mathrm{d}, *}(443 / 555 \mathrm{~nm}) \\
{[\text { dimensionless] }}\end{array}$} \\
\hline & & & {$\left[\mathrm{yr}^{-1}\right]$} & {$\left[\% \mathrm{yr}^{-1}\right]$} & [dimensionless] & {$[\%]$} & \\
\hline \multirow{5}{*}{ 1. BeNeLux } & MAM (Spring) & $0.28 / 0.24$ & $-0.00163 /-0.00181$ & $-0.59 /-0.75$ & $0.00192 / 0.00172$ & $0.69 / 0.71$ & $0.85 / 1.05$ \\
\hline & JJA (Summer) & $0.34 / 0.29$ & $-0.01636 /-0.01643$ & $-4.77 /-5.72$ & $0.00259 / 0.00273$ & $0.75 / 0.95$ & $6.32 / 6.03$ \\
\hline & SON (Fall) & $0.16 / 0.14$ & $-0.00130 /-0.00085$ & $-0.81 /-0.60$ & $0.00070 / 0.00052$ & $0.43 / 0.37$ & $1.87 / 1.64$ \\
\hline & DJF (Winter) & $0.13 / 0.14$ & $-0.00411 /-0.00441$ & $-3.07 /-3.23$ & $0.00085 / 0.00120$ & $0.64 / 0.88$ & 4.82/3.68 \\
\hline & All Seasons & $0.24 / 0.21$ & $-0.00453 /-0.00484$ & $-1.93 /-2.35$ & $0.00414 / 0.00344$ & $1.76 / 1.67$ & $1.09 / 1.41$ \\
\hline \multirow{5}{*}{ 2. Po Valley } & MAM (Spring) & $0.38 / 0.33$ & $-0.00850 /-0.00877$ & $-2.22 /-2.69$ & $0.00379 / 0.00337$ & $0.99 / 1.03$ & $2.25 / 2.60$ \\
\hline & JJA (Summer) & $0.50 / 0.43$ & $-0.01815 /-0.01964$ & $-3.60 /-4.62$ & $0.00304 / 0.00278$ & $0.60 / 0.65$ & $5.96 / 7.07$ \\
\hline & SON (Fall) & $0.21 / 0.19$ & $-0.00098 /+0.00015$ & $-0.47 /+0.08$ & $0.00215 / 0.00169$ & $1.03 / 0.91$ & $0.46 / 0.09$ \\
\hline & DJF (Winter) & $0.16 / 0.16$ & $+0.00108 /+0.00209$ & $+0.67 /+1.32$ & $0.00044 / 0.00054$ & $0.28 / 0.34$ & 2.43/3.90 \\
\hline & All Seasons & $0.32 / 0.28$ & $-0.00386 /-0.00440$ & $-1.22 /-1.59$ & $0.00599 / 0.00523$ & $1.89 / 1.90$ & $0.64 / 0.84$ \\
\hline \multirow{5}{*}{ 3. Eastern Europe } & MAM (Spring) & $0.27 / 0.22$ & $-0.00287 /-0.00132$ & $-1.08 /-0.61$ & $0.00182 / 0.00109$ & $0.68 / 0.50$ & $1.58 / 1.21$ \\
\hline & JJA (Summer) & $0.33 / 0.26$ & $-0.00808 /-0.00691$ & $-2.42 /-2.63$ & $0.00156 / 0.00129$ & $0.47 / 0.49$ & $5.20 / 5.34$ \\
\hline & SON (Fall) & $0.18 / 0.16$ & $+0.00184 /+0.00232$ & $+1.05 /+1.42$ & $0.00066 / 0.00076$ & $0.37 / 0.47$ & $2.80 / 3.05$ \\
\hline & DJF (Winter) & $0.14 / 0.13$ & $+0.00113 /+0.00103$ & $+0.83 /+0.81$ & $0.00040 / 0.00049$ & $0.29 / 0.39$ & $2.84 / 2.08$ \\
\hline & All Seasons & $0.23 / 0.19$ & $-0.00055 /-0.00019$ & $-0.24 /-0.10$ & $0.00201 / 0.00111$ & $0.88 / 0.58$ & $0.27 / 0.17$ \\
\hline \multirow{5}{*}{ 4. Eastern Mediterranean } & MAM (Spring) & $0.29 / 0.20$ & $-0.00301 /-0.00169$ & $-1.04 /-0.84$ & $0.00308 / 0.00170$ & $1.07 / 0.85$ & $0.98 / 0.99$ \\
\hline & JJA (Summer) & $0.38 / 0.24$ & $-0.00814 /-0.00450$ & $-2.12 /-1.88$ & $0.00149 / 0.00097$ & $0.39 / 0.40$ & $5.48 / 4.65$ \\
\hline & SON (Fall) & $0.18 / 0.14$ & $-0.00178 /-0.00124$ & $-0.96 /-0.89$ & $0.00157 / 0.00082$ & $0.85 / 0.59$ & $1.13 / 1.52$ \\
\hline & DJF (Winter) & $0.11 / 0.09$ & $+0.00240 /+0.00125$ & $+2.24 /+1.34$ & $0.00054 / 0.00042$ & $0.49 / 0.44$ & $4.62 / 3.02$ \\
\hline & All Seasons & $0.24 / 0.17$ & $-0.00079 /-0.00054$ & $-0.32 /-0.32$ & $0.00392 / 0.00191$ & $1.61 / 1.13$ & $0.20 / 0.29$ \\
\hline \multirow{5}{*}{ 5. Pearl River Delta } & MAM (Spring) & $0.74 / 0.65$ & $+0.01071 /+0.01066$ & $+1.46 /+1.64$ & $0.00345 / 0.00342$ & $0.47 / 0.53$ & $3.11 / 3.12$ \\
\hline & JJA (Summer) & $0.74 / 0.66$ & $-0.01149 /-0.01318$ & $-1.56 /-2.01$ & $0.00382 / 0.00450$ & $0.52 / 0.69$ & $3.01 / 2.93$ \\
\hline & SON (Fall) & $0.57 / 0.51$ & $+0.01560 /+0.01411$ & $+2.72 /+2.75$ & $0.00696 / 0.00594$ & $1.21 / 1.16$ & $2.24 / 2.37$ \\
\hline & DJF (Winter) & $0.40 / 0.35$ & $+0.00144 /+0.00008$ & $+0.36 /+0.02$ & $0.00130 / 0.00132$ & $0.32 / 0.37$ & $1.10 / 0.06$ \\
\hline & All Seasons & $0.61 / 0.54$ & $+0.00761 /+0.00625$ & $+1.24 /+1.15$ & $0.00600 / 0.00495$ & $0.98 / 0.91$ & $1.27 / 1.26$ \\
\hline
\end{tabular}

* Cloudy seasons are represented in bold-italic type and Significance values (Sig.) larger than two are expressed in bold type.

$\left\langle\tau_{\lambda}\right\rangle^{\mathrm{a}}$ AOT average.

$\hat{\omega}_{\lambda}^{\mathrm{b}}$ Linear long-term trend of AOTs.

$\sigma_{\hat{\omega}_{\lambda}}^{\mathrm{c}}$ Standard deviation of the AOT trends.

Sig. ${ }^{\mathrm{d}}$ Significance, $\left|\hat{\omega} / \sigma_{\hat{\omega}}\right|$.

atmospheric circulation (Papadimas et al., 2008). However, essentially analysis based on small observations might be not enough to be meaningful. Realistically, the cloudy season trend is easily contaminated by cloud disturbance (not only overestimated AOT in AOT retrieval, but also poorly representative due to less observation) as shown Sect. 3. Therefore, if the cloud-contaminated trends could be excluded or ignored, only negative trends over European regions were dominant.

Surprisingly, over the Pearl River Delta, a negative trend in summer with highly significant values is opposite to positive trends in other seasons. Clearly, the removal processes of aerosol (e.g. strong monsoon and frequent rain) could influence the decrease of AOT in summer. On the other hand, frequent cloud occurrence in summer disturbs the observation of cloud-free aerosol, and misclassification between aerosol and clouds in aerosol retrieval using satellites could easily happen under high relative humidity or meteorological stagnation of the atmosphere (Kim et al., 2007). Therefore, the summer trend of BAER AOT over the Pearl River Delta might be not real, despite the significance value $\left(\left|\hat{\omega} / \sigma_{\hat{\omega}}\right|=3.01\right.$ and 2.93 at 443 and $555 \mathrm{~nm}$, respectively) in summer is larger than two. It should be kept in mind that the annual AOT trend could be influenced strongly by this uncertainty in summer. Detailed values of BAER AOT trends and statistical parameters over the regions are shown in Table 2.

Figure 13 depicts seasonal and annual aerosol optical characteristics (volume size distribution and SSA) from level 2.0 inversion all points data at the AERONET stations (red star and cross symbols in Fig. 1) within the regions. The volume size distribution and SSA could be retrieved under the conditions: AOT $(440 \mathrm{~nm})>0.4$ and solar zenith angle $>50^{\circ}$ because of the theoretical limitations in forward model and inversion assumptions (Dubovik et al., 2000). Through the investigations of these seasonal aerosol properties, it enables to classify aerosol types and to explain why there are some discrepancies between BAER and AERONET AOTs as shown in Fig. 3. von Hoyningen-Huene et al. (2011) discussed that BAER could retrieve AOT underestimated up to $20 \%$ in the very strong pollution (i.e. high AOT having strong absorbing). 
The size distributions over most AERONET stations were dominated by accumulation mode with spectral decrease of SSA towards longer wavelengths. They are typical for an industrial aerosol type (Dubovik et al., 2001). The aerosol optical properties over Crete (dominant coarse mode and spectral decrease of SSA by longer wavelengths) revealed that maritime aerosol and desert dust were predominant. Kalivitis et al. (2007) and Fotiadi et al. (2005) have reported that dust could potentially arrive over Crete. On the other hand, the aerosol properties in Hong Kong, located within the Pearl River Delta, have typical anthropogenic characteristics. Especially interesting is a noticeable increase of aerosol finemode radius in summer. This circumstance has been explained by stagnant synoptic meteorological patterns, secondary aerosol formation, and hygroscopic growth (Kotchenruther et al., 1999; Dubovik et al., 2001). Therefore, the aerosol optical characteristics at Hong Kong support that the main source of the increase in AOT is industrial aerosol, and that cloud uncertainties could have a large impact on the estimation of the summer trend over the Pearl River Delta.

\section{Summary and conclusion}

This study yielded linear long-term trends of AOT retrieved from SeaWiFS observations using BAER for selected regions. Before effectively analyzing the AOT trends retrieved from satellite observations, two validation processes have been performed. First, BAER AOTs have been compared to AERONET AOTs using scattergrams and correlation analysis. This comparison revealed good agreement based on linear correlations and RMSDs. However, there were also some discrepancies caused by unscreened clouds, miscalculated surface contribution, and inadequate aerosol optical properties.

In spite of these retrieval uncertainties, after applying an inter-correction method for non-representative data the comparison of trends of BAER and AERONET AOTs exhibited a good correlation. Assessing the validation of trends, we can conclude that one of the largest uncertainties in AOT trend analysis is caused by cloud disturbances. Accordingly, the cloud induced errors will be larger during cloudy seasons (winter in Europe and summer in South China).

We have investigated seasonal AOT trends in order to identify cloud-contamination. The annual and seasonal trends for the past decade over all European regions (especially, BeNeLux and Po Valley) were most likely negative due to environmental regulation. Seasonal aerosol size distribution and SSA at AERONET stations within the European regions also supported that industrial aerosol are dominant except for the station on Crete. Excluding cloud-contaminated scenes, our conclusion that aerosol emission has been decreasing over wide areas of Europe is clearly supported. Conversely, the increasing AOT trend in the region of the Pearl River Delta was actually affected by the constant condition of eco- nomical development and industrial aerosol emission. The strong negative trend in summer may be explained by increasing aerosol removal processes (e.g. frequent rain and strong monsoon). Furthermore, proceeding from a noticeable hygroscopic growth with high relative humidity and meteorological stagnation in summer in Hong Kong (within the Pearl River Delta), it can be concluded that the cloud uncertainties are the most important impact factors in the trend analysis.

The limitation due to cloud contamination can be generalized to other aerosol trend studies using comparable approaches and data. In this respect, the discussion about global brightening and dimming caused by aerosol and measured by space-based observations (Mishchenko et al., 2007; Mishchenko and Geogdzhayev, 2007; Wild et al., 2005, 2007; Ohmura, 2006; Stanhill, 2007; Norris and Wild, 2007; Karnieli et al., 2009; Zhao et al., 2008) need to be extended and reexamined to assess the impact of cloud contamination. Consequently, more continuous cloud-free aerosol measurements utilizing space- and ground-based observations are necessary.

Acknowledgements. This work was supported in part by the CityZen Project (megaCITY - Zoom for the Environment: EU Framework Programme 7 of European Commission), ACCENT Plus Project (Atmospheric Composition Change: the European Network), and University of Bremen. The authors would like to thank the NASA ocean colour group and the AERONET team for providing the SeaWiFS upwelling reflectance and aerosol optical properties data used in the study. The authors sincerely appreciate your insightful comments and suggestions of the editor (M. Kanakidou) and two anonymous referees for revising the paper.

Edited by: M. Kanakidou

\section{References}

Ansmann, A., Wandinger, U., Wiedensohler, A., and Leiterer, U.: Lindenberg Aerosol Characterization Experiment 1998 (LACE 98): Overview, J. Geophys. Res., 107, 8129-8140, doi:10.1029/2000JD000233, 2002.

Barnes, R. A., Eplee Jr., R. E., Schmidt, G. M., Patt, F. S., and McClain, C. R.: Calibration of SeaWiFS, I: Direct techniques, Appl. Optics, 40, 6682-6700, doi:10.1364/AO.40.006682, 2001.

Bergamo, A., Tafuro, A. M., Kinne, S., De Tomasi, F., and Perrone, M. R.: Monthly-averaged anthropogenic aerosol direct radiative forcing over the Mediterranean based on AERONET aerosol properties, Atmos. Chem. Phys., 8, 6995-7014, doi:10.5194/acp8-6995-2008, 2008.

Bruegge, C. J., Diner, D. J., Kahn, R. A., Chrien, N., Helmlinger, M. C., Gaitley, B. J., and Abdou, W. A.: The MISR radiometric calibration process, Remote Sens. Environ., 107, 2-11, doi:10.1016/j.rse.2006.07.024, 2007.

Bundke, U., Hänel, G., Horvath, H., Kaller, W., Seidl, S., Wex, H., Wiedensohler, A., Wiegner, M., and Freudenthaler, V.: Aerosol optical properties during the Lindenberg Aerosol Characteriza- 
tion Experiment (LACE 98), J. Geophys. Res., 107, 8123-8137, doi:10.1029/2000JD000188, 2002.

Colette, A., Granier, C., Hodnebrog, Ø., Jakobs, H., Maurizi, A., Nyiri, A., Bessagnet, B., D’Angiola, A., D'Isidoro, M., Gauss, M., Meleux, F., Memmesheimer, M., Mieville, A., Rouill, L., Russo, F., Solberg, S., Stordal, F., and Tampieri, F.: Air quality trends in Europe over the past decade: a first multi-model assessment, Atmos. Chem. Phys., 11, 11657-11678, doi:10.5194/acp11-11657-2011, 2011.

Cracknell, A. P., Newcombe, S. K., Black, A. F., and Kirby, N. E.: The ABDMAP (Algal Bloom Detection, Monitoring and Prediction) Concerted Action, Int. J. Remote Sens., 22, 205-247, 2001.

de Meij, A., Pozzer, A., and Lelieveld, J.: Global and regional trends in aerosol optical depth based on remote sensing products and pollutant emission estimates between 2000 and 2009, Atmos. Chem. Phys. Discuss., 10, 30731-30776, doi:10.5194/acpd-1030731-2010, 2010.

Di Girolamo, L. and Wilson, M. J.: A first look at banddifferenced angular signatures for cloud detection from MISR, IEEE T. Geosci. Remote, 41, 1730-1734, doi:10.1109/TGRS.2003.815659, 2003.

Dey, S. and Di Girolamo, L.: A decade of change in aerosol properties over the Indian subcontinent, Geophys. Res. Lett., 38, L14811, doi:10.1029/2011GL048153, 2011.

Diner, D. J., Abdou, W. A., Ackerman, T. P., Crean, K., Gordon, H. R., Kahn, R. A., Martonchik, J. V., Paradise, S. R., Pinty, B., Verstraete, M. M., Wang, M., and West, R. A.: Multi-angle Imaging SpectroRadiometer Level 2 Aerosol Retrieval Algorithm Theoretical Basis, Revision F. Jet Propulsion Laboratory, JPL D11400, California Institute of Technology, 2006.

Dubovik, O. and King, M. D.: A flexible inversion algorithm for retrieval of aerosol optical properties from Sun and sky radiance measurements, J. Geophys. Res., 105, 20673-20696, 2000.

Dubovik, O., Smirnov, A., Holben, B. N., King, M. D., Kaufman, Y. J., Eck, T. F., and Slutsker, I.: Accuracy assessment of aerosol optical properties retrieval from AERONET sun and sky radiance measurements, J. Geophys. Res., 105, 9791-9806, 2000.

Dubovik, O., Holben, B. N., Eck, T. F., Smirnov, A., Kaufman, Y. J., King, M. D., Tanré, D., and Slutsker, I.: Variability of absorption and optical properties of key aerosol types observed in worldwide locations, J. Atmos. Sci., 59, 590-608, 2001.

Dubovik, O., Holben, B. N., Lapyonok, T., Sinyuk, A., Mishchenko, M. I., Yang, P., and Slutsker, I.: Nonspherical aerosol retrieval method employing light scattering by spheroids, Geophys. Res. Lett., 10, 1415-1418, doi:10.1029/2001GL014506, 2002.

Dubovik, O., Sinyuk, A., Lapyonok, T., Holben, B. N., Mishchenko, M., Yang, P., Eck, T. F., Volten, H., Munoz, O., Veihelmann, B., van der Zander, W. J., Leon, J.-F., Sorokin, M., and Slutsker, I.: Application of light scattering by spheroids for accounting for particle non-sphericity in remote sensing of desert dust, J. Geophys. Res., 111, D11208, doi:10.1029/2005JD006619, 2006.

Eck, T. F., Holben, B. N., Reid, J. S., Dubovik, O., Smirnov, A., O'Neill, N. T., Slutsker, I., and Kinne, S.: Wavelength dependence of the optical depth of biomass burning, urban, and desert dust aerosol, J. Geophys. Res., 104, 31333-31350, 1999.

Eplee Jr., R. E., Robinson, W. D., Bailey, S. W., Clark, D. K., Werdell, P. J., Wang, M., Barnes, R. A., and McClain, C. R.:
The calibration of SeaWiFS, Part 2: Vicarious techniques, Appl. Optics, 40, 6701-6718, doi:10.1364/AO.40.006701, 2001.

Eplee Jr., R. E., Patt, F. S., Barnes, R. A., and McClain, C. R.: SeaWiFS long-term solar diffuser reflectance and sensor noise analyses, Appl. Optics, 46, 762-773, 2007.

Eplee Jr., R. E., Meister, G., Patt, F. S., Franz, B. A., and McClain, C. R.: Uncertainty Assessment of the SeaWiFS On-Orbit Calibration, Proc. SPIE, 8153, 81530B, doi:10.1117/12.892340, 2011.

Fotiadi, A., Hatzianastassiou, N., Matsoukas, C., Pavlakis, K. G., Drakakis, E., Hatzidimitriou, D., and Vardavas, I.: Analysis of the decrease in the tropical mean outgoing shortwave radiation at the top of atmosphere for the period 1984-2000, Atmos. Chem. Phys., 5, 1721-1730, doi:10.5194/acp-5-1721-2005, 2005.

Franz, B. A., Bailey, S. W., Werdell, P. J., and McClain, C. R.: Sensorindependent Approach to the Vicarious Calibration of Satellite Ocean Color Radiometry, Appl. Optics, 46, 5068-5082, 2007.

Gerasopoulos, E., Andreae, M. O., Zerefos, C. S., Andreae, T. W., Balis, D., Formenti, P., Merlet, P., Amiridis, V., and Papastefanou, C.: Climatological aspects of aerosol optical properties in Northern Greece, Atmos. Chem. Phys., 3, 2025-2041, doi:10.5194/acp-3-2025-2003, 2003.

Gerasopoulos, E., Amiridis, V., Kazadzis, S., Kokkalis, P., Eleftheratos, K., Andreae, M. O., Andreae, T. W., El-Askary, H., and Zerefos, C. S.: Three-year ground based measurements of aerosol optical depth over the Eastern Mediterranean: the urban environment of Athens, Atmos. Chem. Phys., 11, 2145-2159, doi:10.5194/acp-11-2145-2011, 2011.

Gordon, H. R.: In-orbit calibration strategy for ocean color sensors, Remote Sens. Environ., 63, 265-278, 1998.

Grey, W. M. F., North, P., and Los, S.: Computationally efficient method for retrieving aerosol optical depth from ATSR-2 and AATSR data, Appl. Optics, 45, 2786-2795, 2006.

Hatzianastassiou, N., Gkikas, A., Mihalopoulos, N., Torres, O., and Katsoulis, B. D.: Natural versus anthropogenic aerosols in the eastern Mediterranean basin derived from multiyear TOMS and MODIS satellite data, J. Geophys. Res., 114, D24202, doi:10.1029/2009JD011982, 2009.

Haywood, J. M., Francis, P. N., Geogdzhayev, I., Mishchenko, M., and Frey, R.: Comparison of Saharan dust aerosol optical depths retrieved using aircraft mounted pyranometers and 2-channel AVHRR algorithms, Geophys. Res. Lett., 28, 2393-2396, 2001.

Heidinger, A. K., Cao, C., and Sullivan, J.: Using Moderate Resolution Imaging Spectrometer (MODIS) to calibrate Advanced Very High Resolution Radiometer (AVHRR) reflectance channels, J. Geophys. Res., 107, 4702, doi:10,1029/2001JD002035, 2002.

Heidinger, A. K., Goldberg, M. D., Tarpley, D., Jelenak, A., and Pavolonis, M.: A new AVHRR cloud climatology. Applications with Weather Satellites II, Honolulu, Hawaii, 9-11 November 2004, Call Number: Reprint \#4198, Proceedings SPIE-The International Society for Optical Engineering, Bellingham, WA, 197-205, 2004.

Herman, J. R., Bhartia, P. K., Torres, O., Hsu, C., Seftor, C., and Celarier, E.: Global distribution of UV-absorbing aerosols from Nimbus 7/TOMS data, J. Geophys. Res., 102, 16911-16922, 1997.

Higurashi, A. and Nakajima, T.: Development of a two channel 
aerosol retrieval algorithm on global scale using NOAA AVHRR, J. Atmos. Sci., 56, 924-941, 1999.

Higurashi, A., Nakajima, T., Holben, B. N., Smirnov, A., Frouin, R., and Chatenet, B.: A study of global aerosol optical climatology with two-channel AVHRR remote sensing, J. Climate, 13, 2011-2027, doi:10.1175/15200442(2000)013;2011:ASOGAO 2 2.0.CO;2, 2000.

Holben, B. N., Eck, T. F., Slutsker, I., Tanré, D., Buis, J. P., Setzer, A., Vermote, E., Reagan, J. A., Kaufman, Y. J., Nakajima, T., Lavenu, F., Jankowiak, I., and Smirnov, A.: AERONET - A federated instrument network and data archive for aerosol characteristics, Remote Sens. Environ., 66, 1-16, 1998.

Holben, B. N., Tanré, D., Smirnov, A., Eck, T. F., Slutsker, I., Abuhassan, N., Newcomb, W. W., Schafer, J. S., Chatenet, B., Lavenu, F., Kaufman, Y. J., Vande Castle, J., Setzer, A., Markham, B., Clark, D., Frouin, R., Halthore, R., Karneli, A., O’Neill, N. T., Pietras, C., Pinker, R. T., Voss, K., and Zibordi, G.: An emerging ground-based aerosol climatology: Aerosol optical depth from AERONET, J. Geophys. Res., 106, 1206712097, 2001.

Hooker, S. B., Esaias, W. E., Feldman, G. C., Gregg, W. W., and McClain, C. R.: An Overview of SeaWiFS and Ocean Color, NASA Tech. Memo., 1, 104566, 24, 1992.

Husar, R. B., Prospero, J. M., and Stowe, L. L.: Characterization of tropospheric aerosols over the oceans with the NOAA advanced very high resolution radiometer optical thickness operational product, J. Geophys. Res., 102, 16889-16910, 1997.

Ignatov, A. and Stowe, L.: Sensitivity and information content of aerosol retrievals from AVHRR: Radiometric factors, Appl. Optics, 41, 991-1011, doi:10.1364/AO.41.000991, 2002.

Jeong, M.-J. and Li, Z.: Quality, compatibility, and synergy analyses of global aerosol products of global aerosol products derived from the advanced very high resolution radiometer and Total Ozone Mapping Spectrometer, J. Geophys. Res., 110, D10S08, doi:10.1029/2004JD004647, 2005.

Jeong, M.-J., Li, Z., Chu, D. A., and Tsay, S.-T.: Quality and compatibility analyses of global aerosol products derived from the advanced very high resolution radiometers and the moderate imaging spectroradiometer, J. Geophys. Res., 110, D10S09, doi:10.1029/2004JD004648, 2005.

Kahn, R. A., Gaitley, B., Martonchik, J., Diner, D., Crean, K., and Holben, B.: MISR global aerosol optical depth validation based on two years of coincident AERONET observations, J. Geophys. Res., 110, D10S04, doi:10.1029/2004JD004706, 2005 a.

Kahn, R., Li, W.-H., Martonchik, J., Bruegge, C., Diner, D., Gaitley, B., Abdou, W., Dubovik, O., Holben, B., Smirnov, S., Jin, Z., and Clark, D.: MISR low-light-level calibration, and implications for aerosol retrieval over dark water, J. Atmos. Sci., 62, 1032-1062, doi:10.1175/JAS3390.1, 2005b.

Kahn, R. A., Gaitley, B. J., Garay, M. J., Diner, D. J., Eck, T. F., Smirnov, A., and Holben, B. N.: Multiangle Imaging SpectroRadiometer global aerosol product assessment by comparison with the Aerosol Robotic Network, J. Geophys. Res., 25, D23209, doi:10.1029/2010JD014601, 2010.

Kalivitis, N., Gerasopoulos, E., Vrekoussis, M., Kouvarakis, G., Kubilay, N., Hatzianastassiou, N., Vardavas, I., and Mihalopoulos, N.: Dust transport over the eastern Mediterranean derived from Total Ozone Mapping Spectrometer, Aerosol Robotic Network, and surface measurements, J. Geophys. Res., 112,
D03202, doi:10.1029/2006JD007510, 2007.

Karnieli, A., Derimian, Y., Indoitu, R., Panov, N., Levy, R. C., Remer, L. A., Maenhaut, W., and Holben, B. N.: Temporal trend in anthropogenic sulfur aerosol transport from central and eastern Europe to Israel, J. Geophys. Res., 114, D00D19, doi:10.1029/2009JD011870, 2009.

Kaufman, Y. J., Tanré, D., Gordon, H. R., Nakajima, T., Lenoble, J., Frouin, R., Grassl, H., Herman, B. M., King, M. D., and Teillet, P. M.: Passive remote sensing of tropospheric aerosol and atmospheric correction for the aerosol effect, J. Geophys. Res., 102, 16815-16830, 1997.

Kim, S.-W., Yoon, S.-C., Kim, J., and Kim, S.-Y.: Seasonal and monthly variations of columnar aerosol optical properties over East Asia determined from multi-year MODIS, LIDAR, and AERONET sun/sky radiometer measurements, Atmos. Environ., 41, 1634-1651, 2007.

Kishcha, P., Starobinets, B. , Kalashnikova, O., Long, C. N., and Alpert, P.: Variations of meridional aerosol distribution and solar dimming, J. Geophys. Res., 114, D00D14, doi:10.1029/2008JD010975, 2009.

Kokhanovsky, A. A.: Reflection and transmission of polarized light by optically thick weakly absorbing random media, J. Opt. Soc. Am., 18, 883-887, 2001.

Kotchenruther, R., Hobbs, P. V., and Hegg, D. A.: Humidification factors for atmospheric aerosols off the mid-Atlantic coast of the United States, J. Geophys. Res., 104, 2239-2251, 1999.

Koukouli, M. E., Kazadzis, S., Amiridis, V., Ichoku, C., Balis, D. S., and Bais, A. F.: Signs of a negative trend in the MODIS aerosol optical depth over the Southern Balkans, Atmos. Environ., 44, 1219-1228, 2010.

Lee, K. H., Kim, Y. J., and von Hoyningen-Huene, W.: Estimation of aerosol optical thickness over northeast Asia from SeaViewing Wide Field-of-View Sensor (SeaWiFS) data during the 2001 ACE-Asia intensive observation period, J. Geophys. Res., 109, D19S16, doi:10.1029/2003JD004126, 2004.

Lei, Y., Zhang, Q., He, K. B., and Streets, D. G.: Primary anthropogenic aerosol emission trends for China, 1990-2005, Atmos. Chem. Phys., 11, 931-954, doi:10.5194/acp-11-931-2011, 2011.

Leibensperger, E. M., Mickley, L. J., Jacob, D. J., Chen, W.-T., Seinfeld, J. H., Nenes, A., Adams, P. J., Streets, D. G., Kumar, N., and Rind, D.: Climatic effects of 1950-2050 changes in US anthropogenic aerosols - Part 1: Aerosol trends and radiative forcing, Atmos. Chem. Phys. Discuss., 11, 24085-24125, doi:10.5194/acpd-11-24085-2011, 2011.

Lelieveld, J., Berresheim, H., Borrmann, S., Crutzen, P. J., Dentener, F. J., Fischer, H., Feichter, J., Flatau, P. J., Heland, J., Holzinger, R., Korrmann, R., Lawrence, M. G., Levin, Z., Markowicz, K. M., Mihalopoulos, N., Minikin, A., Ramanathan, V., de Reus, M., Roelofs, G. J., Scheeren, H. A., Sciare, J., Schlager, H., Schultz, M., Siegmund, P., Steil, B., Stephanou, E. G., Stier, P., Traub, M., Warneke, C., Williams, J., and Ziereis, H.: Global air pollution crossroads over the Mediterranean, Science, 298, 794-799, 2002.

Levy, R. C., Remer, L. A., Kleidman, R. G., Mattoo, S., Ichoku, C., Kahn, R., and Eck, T. F.: Global evaluation of the Collection 5 MODIS dark-target aerosol products over land, Atmos. Chem. Phys., 10, 10399-10420, doi:10.5194/acp-10-10399-2010, 2010.

Li, Z., Zhao, X., Kahn, R., Mishchenko, M., Remer, L., Lee, K.-H., Wang, M., Laszlo, I., Nakajima, T., and Maring, H.: Uncertain- 
ties in satellite remote sensing of aerosols and impact on monitoring its long-term trend: a review and perspective, Ann. Geophys., 27, 2755-2770, doi:10.5194/angeo-27-2755-2009, 2009.

Marmer, E., Langmann, B., Fagerli, H., and Vestreng, V.: Direct shortwave radiative forcing of sulphate aerosol over Europe from 1900 to 2000, J. Geophys. Res., 112, D23S17, doi:10.1029/2006JD008037, 2007.

Martins, J. V., Remer, L., Kaufman, Y. J., Mattoo, S., and Levy, R.: MODIS cloud screening for remote sensing of aerosols over oceans using spatial variability, Geophys. Res. Lett., 29, 8009, doi:10.1029/2001GL013252, 2002.

Martonchik, J. V., Diner, D. J., Kahn, R. A., Gaitley, B. J., and Holben, B. N.: Comparison of MISR and AERONET aerosol optical depths over desert sites, Geophys. Res. Lett., 31, L16101, doi:10.1029/2004GL019807, 2004.

Massie, T. S., Torres, O., and Smith, S. J.: Total ozone mapping spectrometer (TOMS) observations of increases in Asian aerosol in winter from 1979 to 2000, J. Geophys. Res., 109, D18211, doi:10.1029/2004JD004620, 2004.

Mishchenko, M. and Geogdzhayev, I. V.: Satellite remote sensing reveals regional tropospheric aerosol trends, Opt. Express, 15, 7423-7438, 2007.

Mishchenko, M. I., Geogdzhayev, I. V., Cairns, B., Rossow, W. B., and Lacis, A. A.: Aerosol retrievals over the ocean by use of channels 1 and 2 AVHRR data: sensitivity analysis and preliminary results, Appl. Optics, 38, 7325-7341, 1999.

Mishchenko, M., Geogdzhayev, I. V., Rossow, W. B., Cairns, B., Carlson, B. E., Lacis, A. A., Liu, L., and Travis, L. D.: Longterm satellite record reveals likely recent aerosol trend, Science, 315, p. 1543, doi:10.1126/science.1136709, 2007.

Nakienovi, N. and Swart, R.: Special Report on Emission Scenarios. A Special Report of the Working Group III of Intergovernmental Panel on Climate Change, in: A Special Report of the Working Group III of Intergovernmental Panel on Climate Change, Cambridge University Press, Cambridge, UK and New York, NY USA, 569 pp., 2000.

Norris, J. R. and Wild, M.: Trends in aerosol radiative effects over Europe inferred from observed cloud cover, solar "dimming”, and solar "brightening”, J. Geophys. Res., 112, D08214, doi:10.1029/2006JD007794, 2007.

Ohmura, A.: Observed long-term variations of solar irradiance at the Earth's surface, Space Sci. Rev., 125, 111-128, 2006.

Pace, G., di Sarra, A., Meloni, D., Piacentino, S., and Chamard, P.: Aerosol optical properties at Lampedusa (Central Mediterranean). 1. Influence of transport and identification of different aerosol types, Atmos. Chem. Phys., 6, 697-713, doi:10.5194/acp-6-697-2006, 2006.

Papadimas, C. D., Hatzianastassiou, N., Mihalopoulos, N. , Querol, X., and Vardavas, I.: Spatial and temporal variability in aerosol properties over the Mediterranean basin based on 6year (2000-2006) MODIS data, J. Geophys. Res., 113, D11205, doi:10.1029/2007JD009189, 2008.

Patt, F.: SeaWiFS Status, MODIS Science Meetings, February 5, 2010.

Remer, L. A., Gasso, S., Hegg, D. A., Kaufman, Y. J., and Holben, B. N.: Urban/industrial aerosol: Ground-based sun/sky radiometer and airborne in situ measurements, J. Geophys. Res., 102, 16849-16859, 1997.

Remer, L. A., Kaufman, Y. J., Tanré, D., Mattoo, S., Chu, D. A.,
Martins, J. V., Li, R.-R., Ichoku, C., Levy, R. C., Kleidman, R. G., Eck, T. F., Vermote, E., and Holben, B. N.: The MODIS Aerosol Algorithm, Products, and Validation, J. Atmos. Sci., 62, 947-973, 2005.

Remer, L. A., Kleidman, R. G., Levy, R. C., Kaufman, Y. J., Tanré, D., Mattoo, S., Martins, J. V., Ichoku, C., Koren, I., Yu, H., and Holben, B. N.: Global aerosol climatology from the MODIS satellite sensors, J. Geophys. Res., 113, D14S07, doi:10.1029/2007JD009661, 2008.

Robinson, W. D., Franz, B. A., Patt, F. S., Bailey, S. W., and Werdell, P. J.: Masks and flags updates, NASA Goddard Space Flight Center, Greenbelt, Maryland, edited by: Hooker, S. B. and Firestone, E. R., SeaWiFS Postlaunch Technical Report Series, 22, NASA Tech. Memo. 2003-206892, 2003.

Rossow, W. B. and Schiffer, R. A.: Advances in understanding clouds from ISCCP, B. Am. Meteorol. Soc., 80, 2261-2287, doi:10.1175/1520-0477(1999)080<2261:AIUCFI>2.0.CO;2, 1999.

Sinyuk, A., Dubovik, O., Holben, B. N., Eck, T. F., Breon, F.-M., Martonchik, J., Kahn, R., Diner, D. J., Vermote, E. F., Roger, J.-C., Lapyonok, T., and Slutsker, I.: Simultaneous retrieval of aerosol and surface properties from a combination of AERONET and satellite data, Remote Sens. Environ., 107, 90-108, 2007.

Smirnov, A., Holben, B. N., Eck, T. F., Dubovik, O., and Slutsker, I.: Cloud screening and quality control algorithms for the AERONET data base, Remote Sens. Environ., 73, 337-349, 2000.

Smirnov, A., Holben, B. N., Eck, T. F., Slutsker, I., Chatenet, B., and Pinker, R. T.: Diurnal variability of aerosol optical depth observed at AERONET (Aerosol Robotic Network) sites, Geophys. Res. Lett., 29, 2115, doi:10.1029/2002GL016305, 2002.

Smith, S. J., Pitcher, H., and Wigley, T. M. L.: Global and regional anthropogenic sulfur dioxide emissions, Global Planet. Change, 29, 99-119, 2001.

Stanhill, G.: A perspective on global warming, dimming, and brightening, EOS T. Am. Geophys. Un., 88, 5, p. 58, doi:10.1029/2007EO050007, 2007.

Stowe, L. L., Davis, P. A., and McClain, E. P.: Scientific basis and initial evaluation of the CLAVR-1 global clear/cloud classification algorithm for the Advanced Very High Resolution Radiometer, J. Atmos. Ocean. Tech., 16, 656-681, doi:10.1175/15200426(1999)016<0656:SBAIEO > 2.0.CO;2, 1999.

Streets, D. G., Wu, Y., and Chin, M.: Two-decadal aerosol trends as a likely explanation of the global dimming/brightening transition, Geophys. Res. Lett., 33, L15806, doi:10.1029/2006GL026471, 2006.

Streets, D. G., Yan, F., Chin, M., Diehl, T., Mahowald, N., Schultz, M., Wild, M., Wu, Y., and Yu, C.: Anthropogenic and natural contributions to regional trends in aerosol optical depth, 1980-2006, J. Geophys. Res., 114, D00D18, doi:10.1029/2008JD011624, 2009.

Tafuro, A. M., De Tomasi, F., and Perrone, M. R.: Remote Sensing of Aerosols by Sunphotometers and Lidar Techniques, Chapter 14, in: Advanced Environmental Monitoring, edited by: Kim, Y. J. and Platt, U., ISBN 978-1-4020-6363-3, XXII, Springer, 179189, 2008.

Thomas, G. E., Carboni, E., Sayer, A. M., Poulsen, C. A., Siddans, R., and Grainger, R. G.: Oxford-RAL Aerosol and Cloud (ORAC): Aerosol retrievals from satellite radiometers, in: 
Aerosol remote sensing over land, edited by: Kokhanovsky, A. A. and de Leeuw, G., Springer, Berlin, 2009.

Thomas, G. E., Poulsen, C. A., Siddans, R., Sayer, A. M., Carboni, E., Marsh, S. H., Dean, S. M., Grainger, R. G., and Lawrence, B. N.: Validation of the GRAPE single view aerosol retrieval for ATSR-2 and insights into the long term global AOD trend over the ocean, Atmos. Chem. Phys., 10, 4849-4866, doi:10.5194/acp-10-4849-2010, 2010.

Tiao, G. C., Reinsel, G. C., Xu, D., Pedrick, J. H., Zhu, X., Miller, A. J., DeLuisi, J. J., Mateer, C. L., and Wuebbles, D. J.: Effects of autocorrelation and temporal sampling schemes on estimates of trend and spatial correlation, J. Geophys. Res., 95, 2050720517, 1990 .

Torres, O., Bhartia, P. K., Herman, J. R., Ahmad, Z., and Gleason, J.: Derivation of aerosol properties from satellite measurements of backscattered ultraviolet radiation: Theoretical basis, J. Geophys. Res., 103, 17099-17110, 1998.

Torres, O., Bhartia, P. K., Herman, J. R., Sinyuk, A., and Holben, B.: A long term record of aerosol optical thickness from TOMS observations and comparison to AERONET measurements, J. Atmos. Sci., 59, 398-413, 2002.

Veefkind, J. P., de Leeuw, G., and Durkee, P. A.: Retrieval of aerosol optical depth over land using two-angle view satellite radiometry during TARFOX, Geophys. Res. Lett., 25, 3135-3138, 1998.

Venzac, H., Sellegri, K., Villani, P., Picard, D., and Laj, P.: Seasonal variation of aerosol size distributions in the free troposphere and residual layer at the puy de Dôme station, France, Atmos. Chem. Phys., 9, 1465-1478, doi:10.5194/acp-9-1465-2009, 2009.

von Hoyningen-Huene, W., Freitag, M., and Burrows, J. P.: Retrieval of aerosol optical thickness over land surfaces from top-of-atmosphere radiance, J. Geophys. Res., 108, D94260, doi:10.1029/2001JD002018, 2003.

von Hoyningen-Huene, W., Kokhanovsky, A. A., Burrows, J. P., Bruniquel-Pinel, V., Regner, P., and Baret, F.: Simultaneous Determination of Aerosol- and Surface Characteristics from Top-ofAtmosphere Reflectance using MERIS on board of ENVISAT, J. Adv. Space Res., 37, 2172-2177, 2006.

von Hoyningen-Huene, W., Yoon, J., Vountas, M., Istomina, L. G., Rohen, G., Dinter, T., Kokhanovsky, A. A., and Burrows, J. P.: Retrieval of spectral aerosol optical thickness over land using ocean color sensors MERIS and SeaWiFS, Atmos. Meas. Tech., 4, 151-171, doi:10.5194/amt-4-151-2011, 2011.

Wang, M. and Shi, W.: Estimation of ocean contribution at the MODIS near-infrared wave lengths along the east coast of the U.S.: Two case studies, Geophys. Res. Lett., 32, L13606, doi:13610.11029/12005GL022917, 2005.

Weatherhead, E. C., Reinsel, G. C., Tiao, G. C., Meng, X.-L., Choi, D., Cheang, W.-K., Keller, T., DeLuisi, J., Wuebbles, D. J., Kerr, J. B., Miller, A. J., Oltmans, S. J., and Frederick, J. E.: Factors affecting the detection of trends: Statistical considerations and applications to environmental data, J. Geophys. Res., 103, 17149-17161, 1998.
WHO - World Health Organization: Air quality guidelines for Europe, No. 23, 1987.

WHO - World Health Organization: Air quality guidelines for Europe, No. 91, 2000.

WHO - World Health Organization: Air quality guidelines for Europe, 18-20, 2005.

Wild, M., Gilgen, H., Roesch, A., Ohmura, A., Long, C. N., Dutton, E. G., Forgan, B., Kallis, A., Russak, V., and Tsvetkov, A.: From dimming to brightening: Decadal changes in solar radiation at Earth's surface, Science, 308, 847-850, doi:10.1126/science.1103215, 2005.

Wild, M., Ohmura, A., and Makowski, K.: Impact of global dimming and brightening on global warming, Geophys. Res. Lett., 34, L04702, doi:10.1029/2006GL028031, 2007.

Xiao, R., Takegawa, N., Zheng, M., Kondo, Y., Miyazaki, Y., Miyakawa, T., Hu, M., Shao, M., Zeng, L., Gong, Y., Lu, K., Deng, Z., Zhao, Y., and Zhang, Y. H.: Characterization and source apportionment of submicron aerosol with aerosol mass spectrometer during the PRIDE-PRD 2006 campaign, Atmos. Chem. Phys., 11, 6911-6929, doi:10.5194/acp-11-6911-2011, 2011.

Xie, J. and Xia, X.: Long-term trend in aerosol optical depth from 1980 to 2001 in north China, Particuology, 6, 106-111, doi:10.1016/j.partic.2007.11.002, 2008.

Yoon, J., von Hoyningen-Huene, W., Kokhanovsky, A. A., Vountas, M., and Burrows, J. P.: Trend analysis of the Aerosol Optical Thickness and Ångström Exponent derived from the global AERONET spectral observations, Atmos. Meas. Tech. Discuss., 4, 5325-5388, doi:10.5194/amtd-4-5325-2011, 2011.

Yu, H., Chin, M., Remer, L. A., Kleidman, R. G., Bellouin, N., Bian, H., and Diehl, T.: Variability of marine aerosol finemode fraction and estimates of anthropogenic aerosol component over cloud-free oceans from the Moderate Resolution Imaging Spectroradiometer (MODIS), J. Geophys. Res., 114, D10206, doi:10.1029/2008JD010648, 2009.

Zhang, J. and Reid, J. S.: A decadal regional and global trend analysis of the aerosol optical depth using a data-assimilation grade over-water MODIS and Level 2 MISR aerosol products, Atmos. Chem. Phys., 10, 10949-10963, doi:10.5194/acp-1010949-2010, 2010.

Zhang, Y. H., Hu, M., Zhong, L. J., Wiedensohler, A., Liu, S. C., Andreae, M. O., Wang, W., and Fan, S. J.: Regional integrated experiments on air quality over Pearl River Delta 2004 (PRIDEPRD2004): Overview, Atmos. Environ., 42, 6157-6173, 2008.

Zhao, T. X.-P., Laszlo, I., Guo, W., Heidinger, A., Cao, C., Jelenak, A., Tarpley, D., and Sullivan, J.: Study of long-term trend in aerosol optical thickness observed from operational AVHRR satellite instrument, J. Geophys. Res., 113, D07201, doi:10.1029/2007JD009061, 2008. 